\title{
Relationship of Urinary and Blood Carbon Dioxide Tension during Hypercapnia in the Rat

\author{
Its Significance in the Evaluation of Collecting Duct Hydrogen lon Secretion
}

Daniel C. Batlle, Mary Downer, Cory Gutterman, and Neil A. Kurtzman

West Side Veterans Administration Hospital and the University of Illinois College of Medicine,

Department of Medicine, Section of Nephrology, Chicago, Illinois 60612

\section{Abstract}

This study was designed to establish the relationship between urinary $\mathrm{pCO}_{2}$ and systemic blood $\mathrm{pCO}_{2}$ during acute hypercapnia and to investigate the significance of this relationship to collecting duct hydrogen ion $\left(\mathrm{H}^{+}\right)$secretion when the urine is acid and when it is highly alkaline. In rats excreting a highly alkaline urine, an acute increase in blood $\mathrm{pCO}_{2}$ (from $42 \pm 0.8$ to $87 \pm 0.8 \mathrm{mmHg}$ ) resulted in a significant fall in urine minus blood (U-B) $\mathrm{pCO}_{2}$ (from $31 \pm 2.0$ to $16 \pm 4.2 \mathrm{mmHg}, P$ $<0.005$ ), a finding which could be interpreted to indicate inhibition of collecting duct $\mathrm{H}^{+}$secretion by hypercapnia. The urinary $\mathrm{PCO}_{2}$ of rats with hypercapnia, unlike that of normocapnic controls, was significantly lower than that of blood when the urine was acid $(58 \pm 6.3$ and $86 \pm 1.7 \mathrm{mmHg}, P<0.001)$ and when it was alkalinized in the face of accelerated carbonic acid dehydration by infusion of carbonic anhydrase $(78 \pm 2.7$ and $87 \pm 1.8 \mathrm{mmHg}, P<0.02$ ). The finding of a urinary $\mathrm{pCO}_{2}$ lower than systemic blood $\mathrm{pCO}_{2}$ during hypercapnia suggested that the urine $\mathrm{pCO}_{2}$ prevailing before bicarbonate loading should be known and the blood $\mathrm{pCO}_{2}$ kept constant to evaluate collecting duct $\mathrm{H}^{+}$secretion using the urinary $\mathrm{pCO}_{2}$ technique.

In experiments performed under these conditions, sodium bicarbonate infusion resulted in an increment in urinary $\mathrm{pCO}_{2}$ (i.e., a $\triangle \mathrm{pCO}_{2}$ ) which was comparable in hypercapnic and normocapnic rats $(40 \pm 7.2$ and $42 \pm 4.6 \mathrm{mmHg}$, respectively) that were alkalemic (blood $\mathrm{pH} 7.53 \pm 0.02$ and $7.69 \pm 0.01$, respectively). The $\mathrm{U}-\mathrm{B} \mathrm{pCO}_{2}$, however, was again lower in hypercapnic than in normocapnic rats (15 \pm 4.0 and $39 \pm 2.5$ $\mathrm{mmHg}$, respectively, $P<\mathbf{0 . 0 0 1})$. In hypercapnic rats in which blood pH during bicarbonate infusion was not allowed to become alkalemic $(7.38 \pm 0.01)$, the $\Delta \mathrm{pCO}_{2}$ was higher than that of normocapnic rats which were alkalemic $(70 \pm 5.6$ and $42 \pm 4.6 \mathrm{mmHg}$, respectively, $P<0.005$ ) while the $\mathrm{U}-\mathrm{B} \mathrm{pCO}_{2}$ was about the same $(39 \pm 3.7$ and $39 \pm 2.5 \mathrm{mmHg})$. We further examined urine $\mathrm{pCO}_{2}$ generation by measuring the difference between the urine $\mathrm{pCO}_{2}$ of a highly alkaline urine not containing carbonic anhydrase and that of an equally alkaline urine containing this enzyme. Carbonic anhydrase infusion to hypercapnic rats that were not alkalemic resulted in a fall in urine

Portions of this work were presented at the National Meeting of the American Federation of Clinical Research (Washington, DC, 1982).

Address correspondence to Dr. Batlle, University of Illinois Hospital.

Received for publication 8 August 1983 and in revised form 4 January 1985.

J. Clin. Invest.

(c) The American Society for Clinical Investigation, Inc.

$0021-9738 / 85 / 05 / 1517 / 14 \$ 1.00$

Volume 75, May 1985, 1517-1530
$\mathrm{PCO}_{2}$ (from $122 \pm 5.7$ to $77 \pm 2.2 \mathrm{mmHg}$ ) which was greater $(P$ $<\mathbf{0 . 0 2}$ ) than that seen in alkalemic normocapnic controls (from $73 \pm 1.9$ to $43 \pm 1.3 \mathrm{mmHg}$ ) with a comparable urine bicarbonate concentration and urine nonbicarbonate buffer capacity. $\mathrm{CO}_{2}$ generation, therefore, from collecting duct $\mathrm{H}^{+}$secretion and titration of bicarbonate, was higher in hypercapnic rats than in normocapnic controls.

We conclude that in rats with acute hypercapnia, the $U-B$ $\mathrm{pCO}_{2}$ achieved during bicarbonate loading greatly underestimates collecting duct $\mathrm{H}^{+}$secretion because it is artificially influenced by systemic blood $\mathrm{pCO}_{2}$. The $\triangle \mathrm{pCO}_{2}$ is a better qualitative index of collecting duct $\mathrm{H}^{+}$secretion than the $U-B$ $\mathrm{pCO}_{2}$, because it is not artificially influenced by systemic blood $\mathrm{pCO}_{2}$ and it takes into account the urine $\mathrm{pCO}_{2}$ prevailing before bicarbonate loading.

\section{Introduction}

The carbon dioxide tension $\left(\mathrm{pCO}_{2}\right)$ of a highly alkaline urine reaches a value substantially higher than that of systemic blood (1-8). Pitts and Lotspeich (1) proposed that the existence of an appreciable gradient between urine and blood $\mathrm{pCO}_{2}$ was the consequence of distal $\mathrm{H}^{+}$secretion into bicarbonate-rich tubular urine in the face of delayed carbonic acid dehydration. They reasoned that, in the absence of carbonic anhydrase in the lumen of the distal nephron, carbonic acid would not completely dehydrate to carbon dioxide during the time that tubular fluid is in transit through the distal nephron. Completion of carbonic acid dehydration in the renal pelvis would ultimately increase urinary $\mathrm{pCO}_{2}$ because the surface to volume relationship in this region is not favorable for $\mathrm{CO}_{2}$ back diffusion (1).

It is now known from recent direct intrarenal $\mathrm{pCO}_{2}$ determinations that during alkalinization of the urine a near maximal urinary $\mathrm{pCO}_{2}$ is achieved in the papillary collecting duct $(9,10)$. That the rise in urinary $\mathrm{pCO}_{2}$ is an intrarenal rather than a postpapillary event, however, does not invalidate the classic notion that distal $\mathrm{H}^{+}$secretion is largely responsible for the high urinary $\mathrm{pCO}_{2}$ achieved in a highly alkaline urine. Although other explanations have been offered to account for the development of a urine to blood $\mathrm{pCO}_{2}$ gradient $(3,6,7$, $11-17)$, it is generally accepted that distal $\mathrm{H}^{+}$secretion largely accounts for this phenomenon (18-29). The recent finding of a significant disequilibrium $\mathrm{pH}$ in the papillary collecting duct under conditions of bicarbonate loading has been proposed as proof of the notion that $\mathrm{H}^{+}$secretion by the collecting duct is the most likely determinant of the urine minus blood $(U-B)^{1}$ $\mathrm{pCO}_{2}$ gradient observed in an alkaline urine (9).

The $\mathrm{U}-\mathrm{B} \mathrm{pCO}_{2}$ gradient achieved in response to bicarbon-

1. Abbreviations used in this paper: GFR, glomerular filtration rate; $\mathrm{U}-\mathrm{B}$, urine minus blood. 
ate loading, however, may not be the ideal way to express the relationship between urinary $\mathrm{pCO}_{2}$ generation and distal $\mathrm{H}^{+}$ secretion (30). The use of the $\mathrm{U}-\mathrm{B} \mathrm{pCO}_{2}$ as a marker of distal $\mathrm{H}^{+}$secretion assumes that blood $\mathrm{pCO}_{2}$ and urine $\mathrm{pCO}_{2}$ are about the same before alkalinization of the urine. There are situations, however, where the urinary $\mathrm{pCO}_{2}$ can be lower than blood $\mathrm{pCO}_{2}$ as in metabolic and respiratory acidosis (3, 6, 31-33). It also assumes that during bicarbonate loading medullary blood $\mathrm{pCO}_{2}$ is similar to that of systemic blood. The latter assumption was supported by the findings of Uhlich et al. (34), which showed that during bicarbonate loading vasa recta blood $\mathrm{pCO}_{2}$ was not substantially different from that prevailing in systemic blood (as determined by renal artery $\mathrm{pCO}_{2}$ ). Using a recently developed $\mathrm{pCO}_{2}$ microelectrode (3539), DuBose (9), however, found that during bicarbonate loading the $\mathrm{pCO}_{2}$ of the papillary collecting duct is equal to that of its adjacent vasa recta but is markedly higher than systemic blood $\mathrm{pCO}_{2}$. He suggested a role for trapping of $\mathrm{CO}_{2}$ in the medullary countercurrent system to explain the similar values for $\mathrm{pCO}_{2}$ in the papillary collecting duct and its adjacent vasa recta (9).

Although the contribution of $\mathrm{CO}_{2}$ trapping (if any) to urinary $\mathrm{pCO}_{2}$ generation during hypercapnia is unknown, there is no a priori reason to believe that systemic blood $\mathrm{pCO}_{2}$ would reflect vasa recta $\mathrm{pCO}_{2}$ in hypercapnic subjects excreting an alkaline urine. Moreover, it is now known that in rats with acute respiratory acidosis, inner collecting duct $\mathrm{pCO}_{2}$ is lower than that of the blood $(38,39)$. Based on these considerations, we reasoned that the use of the $\mathrm{U}-\mathrm{B} \mathrm{pCO}_{2}$ achieved during bicarbonate loading could be a poor marker of collecting duct $\mathrm{H}^{+}$secretion under conditions where systemic blood $\mathrm{pCO}_{2}$ is altered. Accordingly, we examined urinary $\mathrm{pCO}_{2}$ generation and $\mathrm{U}-\mathrm{B} \mathrm{pCO}_{2}$ gradients in hypercapnic rats studied under conditions where the urine was acid and when it was alkalinized in the presence and in the absence of accelerated carbonic acid dehydration.

\section{Methods}

Adult Sprague-Dawley rats $(250-380 \mathrm{~g})$ were allowed free access to food (Purina Lab Chow, Ralston Purina Co., St. Louis, MO) and water until the morning of each experiment. Studies using conventional clearance techniques were performed in anesthetized rats. Anesthesia was accomplished by the intraperitoneal administration of Inactin (100 $\mathrm{mg} / \mathrm{kg}$ body weight). Tracheostomy was performed and one carotid artery and jugular vein were cannulated. Rats were connected to a rodent respirator (model 680, Harvard Apparatus Co., Inc., S. Natick, MA) to sustain a blood $\mathrm{pCO}_{2}$ at the desired level. At the start of the experiment, ${ }^{125} \mathrm{I}$-iothalamate diluted in saline $(0.75 \mu \mathrm{Ci} / \mathrm{ml})$ was infused by an infusion pump at a rate of $0.024 \mathrm{ml} / \mathrm{min}$ throughout the course of the experiment as a marker of glomerular filtration rate (GFR). An equilibration period of $60 \mathrm{~min}$ was allowed before any collection was started. Urine samples were collected via a suprapubic catheter and drained into preweighed glass vials containing mineral oil; urine volume was determined gravimetrically. Blood samples were collected from the carotid artery during the middle portion of each clearance period.

Timed urine collections of $\sim 20-30$ min duration were obtained in the following groups of rats: in group Ia, eight normocapnic rats were infused with sodium bicarbonate (0.9-M solution) at a rate of 6 $\mathrm{ml} / \mathrm{h}$. At least two clearance collections were obtained from each rat after a urine $\mathrm{pH}$ of 7.8 or higher was achieved. The first urine collection with a urine $\mathrm{pH}$ of 7.8 or higher was discarded to eliminate mixing of urine of different $\mathrm{pH}$ 's. After completion of this protocol, acute hypercapnia was induced in the eight rats by making them inhale a mixture of $10 \% \mathrm{CO}_{2}$, balance air via tracheal intubation. After $2 \mathrm{~h}$ of stable hypercapnia (blood $\mathrm{pCO}_{2}$ range, $80-100 \mathrm{mmHg}$ ), urine collections were obtained while sodium bicarbonate infusion was continued throughout the experiment to keep urinary $\mathrm{pH}$ above 7.8.

In group Ib, nine rats were studied during normocapnia in response to a sodium bicarbonate infusion as described above. After obtaining at least two control clearance collections at a urinary $\mathrm{pH}$ of 7.8 or higher, moderate hypercapnia was induced using a mixture of $5 \%$ $\mathrm{CO}_{2}$, balance air. Blood $\mathrm{pCO}_{2}$ was kept constant between 68 and 78 $\mathrm{mmHg}$ for $2 \mathrm{~h}$. Thereafter, experimental urine collections were completed while sodium bicarbonate infusion was administered as in group Ia.

In group IIa, seven rats were studied before and after induction of severe hypercapnia (blood $\mathrm{pCO}_{2}, 80-100 \mathrm{mmHg}$ ). Urine collections were obtained during the first and the second hour of sustained respiratory acidosis to determine the effect of this acid-base alteration on urinary $\mathrm{pCO}_{2}$ and renal acid excretion.

In group IIb, seven normocapnic rats excreting a urine of low bicarbonate concentration ( $<3 \mathrm{meq} / \mathrm{liter})$ were studied during $2 \mathrm{~h}$ and served as controls for hypercapnic rats excreting an acid urine (group IIa).

In group IIIa, seven rats were studied during severe hypercapnia as in group IIa except that a bolus dose of $5 \mathrm{mg}$ of carbonic anhydrase followed by a continuous infusion $(5 \mathrm{mg} / \mathrm{h})$ was administered before induction of severe hypercapnia. Thereafter, carbonic anhydrase was infused at a rate of $5 \mathrm{mg} / \mathrm{h}$ during $2 \mathrm{~h}$ of sustained hypercapnia to examine urinary $\mathrm{pCO}_{2}$ generation in the face of accelerated carbonic acid dehydration.

In group IIIb, six normocapnic rats were studied during the infusion of carbonic anhydrase as in group IIIb and served as normocapnic controls.

After completion of the above protocols, groups IIa, IIb, IIIa, and IIIb were infused with sodium bicarbonate. In groups IIIa and IIIb, the infusion of carbonic anhydrase was continued throughout the experiment. At least three urine collections were completed during the infusion of sodium bicarbonate (0.9-M solution) at a rate of $6 \mathrm{ml} / \mathrm{h}$ while blood $\mathrm{pCO}_{2}$ was held constant.

In group IV, eleven rats were studied during $2 \mathrm{~h}$ of acute respiratory acidosis as in group IIa. Thereafter, they were infused with sodium bicarbonate at a slower rate $(3 \mathrm{ml} / \mathrm{h})$ in an effort to prevent a rise in blood $\mathrm{pH}$ to the alkalemic range that occurred in all previous groups studied during the course of sodium bicarbonate infusion.

In group IVa, a subset of six rats of group IV were further studied during carbonic anhydrase infusion $(5 \mathrm{mg} / \mathrm{h}$ for $2 \mathrm{~h}$ after an initial bolus dose of $5 \mathrm{mg}$ ). Three collections of $\sim 30 \mathrm{~min}$ duration were obtained while the rate of sodium bicarbonate infusion was maintained at $\sim 3 \mathrm{ml} / \mathrm{h}$.

In groups $\mathrm{Va}$ and $\mathrm{Vb}$, ten normocapnic rats served as controls for group IVa hypercapnic rats. After completion of three urine collections during the infusion of sodium bicarbonate, five of them were given carbonic anhydrase (group $\mathrm{Va}$ ) and five were not (group $\mathrm{Vb}$, time controls). The rate of sodium bicarbonate infusion was maintained at $\sim 3 \mathrm{ml} / \mathrm{h}$ throughout the protocol.

Analytical methods. The urine and arterial blood samples for $\mathrm{pH}$ and $\mathrm{pCO}_{2}$ were measured on a Radiometer system (Radiometer America, Inc., Westlake, $\mathrm{OH}$ ) immediately after collection. Bicarbonate concentration was calculated from the $\mathrm{pH}$ and $\mathrm{pCO}_{2}$ using the Henderson-Hasselbalch equation as previously described $(40,41)$. Sodium and potassium were measured by flame photometry. Titratable acidity was calculated from the amount of $0.1 \mathrm{NaOH}$ used to titrate a $1-\mathrm{ml}$ sample $\left(0.1 \mathrm{ml}\right.$ urine plus $0.9 \mathrm{ml}$ distilled $\left.\mathrm{H}_{2} \mathrm{O}\right)$ up to a pH of 7.4. Ammonium was measured by a formulin titrimetric method (42).

Nonbicarbonate buffer capacity was measured using an automatic titrator (Radiometer America, Inc., model TTT 60, ABU 12) as previously described by Stinebaugh et al. (20). Briefly, $\mathrm{HCl}$ was added in sufficient amounts as to lower the pH of each urine specimen to below 2.5. The specimens were agitated for $30 \mathrm{~min}$ to ensure carbon dioxide loss. Thereafter, a titration curve from 2.5 to 8.5 was obtained by adding $\mathrm{NaOH}(0.1 \mathrm{M})$ to each of the urine samples. The nonbicarbonate buffer capacity was calculated from the $\mathrm{pH} 7.0-8.5$ portion of 
the titration curve as well as from 3.0 to $8.5 \mathrm{pH}$ U. Either calculation yielded similar results, owing to the linearity of the titration curve. Carbonic anhydrase B from bovine erythrocytes was obtained from Sigma Chemical Co. (St. Louis, MO). Carbonic anhydrase activity in the urine was measured by the method of Maren et al. (43). This technique measures carbonic anhydrase activity by the rate of carbon dioxide hydration. Statistical analyses were performed using the $t$ test for paired and unpaired data when appropriate. Values are means \pm SE.

\section{Results}

Effect of an acute elevation of blood $\mathrm{pCO}_{2}$ on urine $\mathrm{pCO}_{2}$ in rats excreting a highly alkaline urine (Table I, Fig. 1)

Effect of severe hypercapnia (group Ia). The data of rats infused with sodium bicarbonate before induction of hypercapnia are presented in Table I. In these rats, urine $\mathrm{pCO}_{2}$ after alkalinization of the urine was $75 \pm 1.6 \mathrm{mmHg}$ and $\mathrm{U}-\mathrm{B} \mathrm{pCO}_{2}$ was $31 \pm 2 \mathrm{mmHg}$. Induction of acute hypercapnia in the face of continuous sodium bicarbonate infusion resulted in a fall in blood $\mathrm{pH}$ and a rise in plasma bicarbonate. The increase in blood $\mathrm{pCO}_{2}$ (from $42 \pm 0.8$ to $87 \pm 0.8 \mathrm{mmHg}$ ) was associated with an increase in urine $\mathrm{pCO}_{2}$ (from $75 \pm 1.6$ to $103 \pm 4.2$ $\mathrm{mmHg}, P<0.001$ ) and a decrease in $\mathrm{U}-\mathrm{B} \mathrm{pCO}_{2}$ (from $31 \pm 2$ to $16 \pm 4.2 \mathrm{mmHg}, P<0.005$ ). The rise in urine $\mathrm{pCO}_{2}$ was of a greater magnitude than the rise in urine bicarbonate concentration (from $163 \pm 5.2$ to $196 \pm 12 \mathrm{meq} / \mathrm{liter}$ ); consequently, urinary pH fell (from $7.93 \pm 0.009$ to $7.87 \pm 0.02, P<0.01$ ).

Effect of moderate hypercapnia (group Ib). In these rats, blood $\mathrm{pCO}_{2}$ was increased to a lesser degree in order to investigate whether the low $\mathrm{U}-\mathrm{B} \mathrm{pCO}_{2}$ observed in rats with severe hypercapnia had been, at least in part, the consequence of their higher blood $\mathrm{pCO}_{2}$ per se, rather than failure to generate a sufficiently large urinary $\mathrm{pCO}_{2}$.

The increase in blood $\mathrm{pCO}_{2}$ (from $40 \pm 0.6$ to $73 \pm 0.06$ $\mathrm{mmHg}$ ) resulted in a fall in blood $\mathrm{pH}$ despite an increase in plasma bicarbonate secondary to continuous sodium bicarbonate infusion. Urinary $\mathrm{pCO}_{2}$ increased from $79 \pm 2.8$ to $103 \pm 5.2$ $\mathrm{mmHg}, P<0.005$; that is, to a value virtually identical to that observed in rats with severe hypercapnia (group Ia). This increase in urine $\mathrm{pCO}_{2}$ occurred in the face of a modest rise in urine bicarbonate concentration (from $145 \pm 4.5$ to $199 \pm 11$ meq/liter) which was also virtually identical to that observed in rats with severe hypercapnia (group Ia) (Fig. 1).

In contrast to rats with severe hypercapnia, however, the $\mathrm{U}-\mathrm{B} \mathrm{pCO}_{2}$ did not decrease significantly in response to induction of hypercapnia of moderate severity (from 39 \pm 2.5 to $30 \pm 4.9 \mathrm{mmHg}$ ). Hence, the $\mathrm{U}-\mathrm{B} \mathrm{pCO}_{2}$ of rats with moderate hypercapnia was significantly higher than that of rats with severe hypercapnia $(30 \pm 4.9$ and $16 \pm 4.2 \mathrm{mmHg}$, respectively; $P<0.05$ ). This difference was likely the consequence of a blood $\mathrm{pCO}_{2}$ lower in rats with moderate hypercapnia than in rats with severe hypercapnia $(73 \pm 0.6$ and $87 \pm 0.8 \mathrm{mmHg}, P<0.001$ ) because urinary $\mathrm{pCO}_{2}$ was virtually identical between both groups (Fig. 1). Blood pH, plasma sodium, plasma potassium, and urine flow were not significantly different between these two groups of hypercapnic animals. After induction of hypercapnia GFR fell to a comparable level in both groups. A fall in GFR was also observed in normocapnic time control rats (group $\mathrm{Vb}$ ) that are presented in Table $\mathrm{V}$ (see below).

Acid excretion during acute respiratory acidosis (Table II) Induction of severe hypercapnia (group IIa) resulted in a significant fall in blood $\mathrm{pH}$, a fall in urinary $\mathrm{pH}$, and an increase in net acid excretion which were observed during the first hour of acute hypercapnia. The increase in titratable acid excretion was associated with an increase in phosphate excretion. A significant increase in ammonium excretion and a further increase in titratable acid and net acid excretion were observed during the second hour of sustained hypercapnia. The increase in ammonium excretion observed during the second hour of sustained hypercapnia was associated with a urinary $\mathrm{pH}$ identical to that observed during the first hour of hypercapnia. As anticipated, plasma $\mathrm{K}$ and plasma phosphate increased in response to hypercapnia. GFR did not fall significantly after induction of acute respiratory acidosis.

\section{Urinary $\mathrm{pCO}_{2}$ during acute respiratory acidosis}

The urinary $\mathrm{pCO}_{2}$ of group IIa rats was $57 \pm 9.1 \mathrm{mmHg}$ in the first hour and $58 \pm 6.3 \mathrm{mmHg}$ during the second hour of sustained hypercapnia. These values of urinary $\mathrm{pCO}_{2}$ were significantly lower than blood $\mathrm{pCO}_{2}(57 \pm 9.1$ vs. $84 \pm 2.2 \mathrm{mmHg}$, $P<0.02$, and $58 \pm 6.3$ vs. $86 \pm 1.7 \mathrm{mmHg}, P<0.005$ ). Therefore, in hypercapnic rats the $\mathrm{U}-\mathrm{B} \mathrm{pCO}_{2}$ difference was markedly negative throughout the $2 \mathrm{~h}$ of observation (Fig. 2). The urinary $\mathrm{pCO}_{2}$ of control rats (group IIb) was not significantly different than that of the blood $(37 \pm 3.2$ and $41 \pm 1.3 \mathrm{mmHg}$, respectively).

The urinary $\mathrm{pCO}_{2}$ observed in group IIa rats during the second hour of hypercapnia was compared to that of normocapnic control rats (group IIb) which were excreting an acid urine. The urinary $\mathrm{pCO}_{2}$ of hypercapnic rats was higher than that of normocapnic control rats $(58 \pm 6.3$ and $37 \pm 3.2 \mathrm{mmHg}$, respectively, $P<0.02$ ) with a comparably low urine bicarbonate concentration $(1.1 \pm 0.3$ and $1.6 \pm 0.3 \mathrm{meq} / \mathrm{liter}$, respectively). Consequently, urinary $\mathrm{pH}$ was lower in hypercapnic rats than in control rats $(5.78 \pm 0.06$ and $6.17 \pm 0.07$, respectively, $P$ $<0.005$ ). Hypercapnic rats had a urinary phosphate concentration higher than that of normocapnic controls (72 \pm 17 and $29 \pm 6.3 \mathrm{mmol} /$ liter, respectively, $P<0.05$ ).

\section{Urinary $\mathrm{pCO}_{2}$ during acute respiratory acidosis and} carbonic anhydrase infusion

In rats with acute respiratory acidosis infused with carbonic anhydrase (group IIIa), urinary $\mathrm{pCO}_{2}$ was $50 \pm 4.3$ and $55 \pm 4.7$ $\mathrm{mmHg}$ during the first and second hour of hypercapnia, respectively. These values of urinary $\mathrm{pCO}_{2}$ were significantly lower than blood $\mathrm{pCO}_{2}(50 \pm 4.3$ vs. $80 \pm 1.5 \mathrm{mmHg}, P<0.001$, and $55 \pm 4.7$ vs. $86 \pm 2.2 \mathrm{mmHg}, P<0.001$, respectively). The urinary $\mathrm{pCO}_{2}$ of these rats was also higher than that of normocapnic controls (group IIIb) infused with carbonic anhydrase $(55 \pm 4.7$ and $30 \pm 3.6 \mathrm{mmHg}$, respectively, $P<0.005)$ (Table III). The urinary $\mathrm{pCO}_{2}$ of hypercapnic rats infused with carbonic anhydrase (group IIIa) was not significantly different from that of hypercapnic rats not receiving this enzyme (group Ila) $(55 \pm 4.7$ and $58 \pm 6.3 \mathrm{mmHg}$, respectively). Hence, the urinary $\mathrm{pCO}_{2}$ of hypercapnic rats excreting a urine of low bicarbonate content was lower than that of the blood regardless of whether carbonic anhydrase was given or not. This resulted in a markedly negative $\mathrm{U}-\mathrm{B} \mathrm{pCO}_{2}$ difference in hypercapnic but not in normocapnic rats (Fig. 2).

Effect of alkalinization of the urine on urinary $\mathrm{pCO}_{2}$ in rats infused with carbonic anhydrase (Table III)

In hypercapnic rats (group IIIa), sodium bicarbonate infusion resulted in a significant rise in urine $\mathrm{pCO}_{2}$ (from $55 \pm 4.7$ to $78 \pm 2.7 \mathrm{mmHg}, P<0.005)$. In normocapnic control rats 


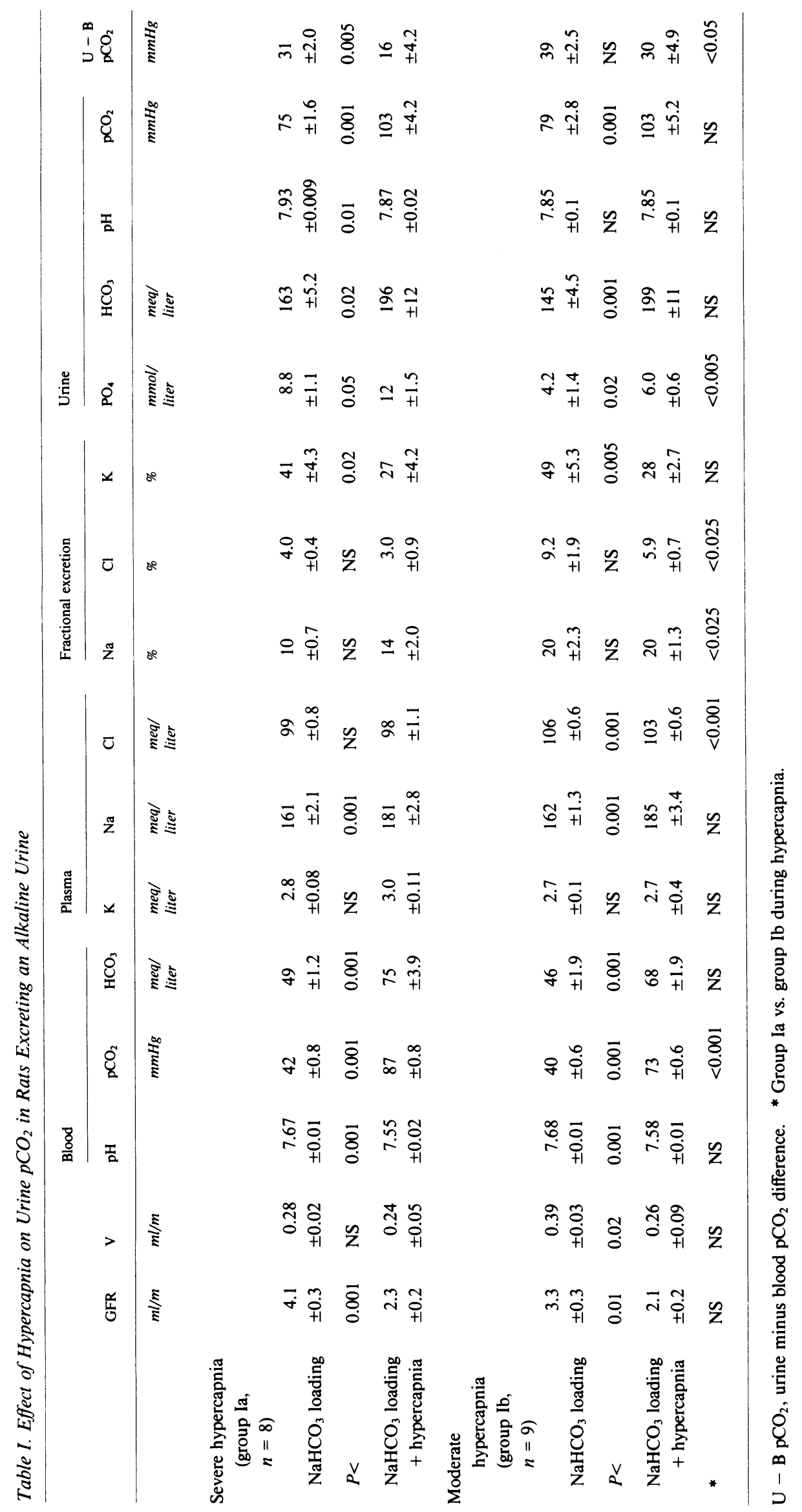

1520 D. C. Batlle, M. Downer, C. Gutterman, and N. A. Kurtzman 

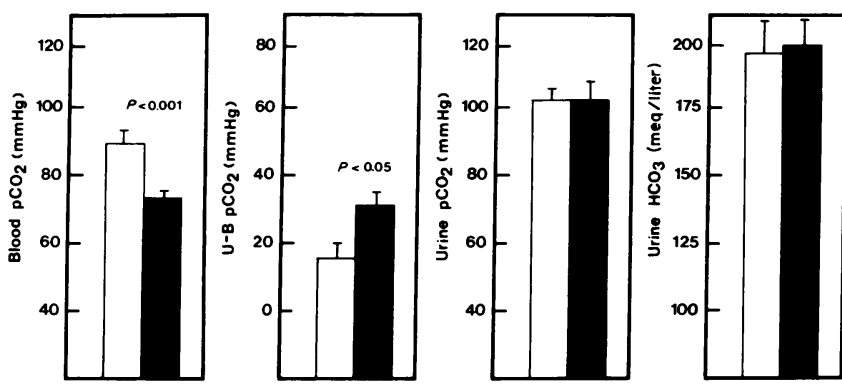

Figure 1. Blood $\mathrm{pCO}_{2}, \mathrm{U}-\mathrm{B} \mathrm{pCO}$, urine $\mathrm{pCO}_{2}$, and urine bicarbonate concentration in rats with severe hypercapnia (open bars) and in rats with moderate hypercapnia (dark bars) infused with sodium bicarbonate. The lower $\mathrm{U}-\mathrm{B} \mathrm{pCO}$ of rats with severe hypercapnia was totally accounted by their higher blood $\mathrm{pCO}_{2}$ because urine $\mathrm{pCO}_{2}$ was the same as that of rats with moderate hypercapnia.

(group IIIb), sodium bicarbonate infusion also resulted in a significant rise in urine $\mathrm{pCO}_{2}$ (from $30.5 \pm 3.6$ to $42 \pm 1.7$ $\mathrm{mmHg}, P<0.02$ ). The increment in urinary $\mathrm{pCO}_{2}$ elicited by sodium bicarbonate loading was higher in hypercapnic than in normocapnic rats $(24 \pm 5.2$ and $12 \pm 3.1 \mathrm{mmHg}$, respectively), but this difference did not achieve statistical significance $(P>0.05)$. During sodium bicarbonate loading, the urine $\mathrm{pCO}_{2}$ of hypercapnic rats was significantly lower than that systemic blood $\mathrm{pCO}_{2}(78 \pm 2.7$ and $87 \pm 1.8 \mathrm{mmHg}$, respectively, $P<0.02)$, while that of normocapnic rats was not $(42 \pm 1.7$ and $40 \pm 0.3 \mathrm{mmHg}$, respectively). This resulted in a negative $\mathrm{U}-\mathrm{B} \mathrm{pCO}_{2}$ in hypercapnic rats but not in controls (Fig. 2).

Urine $\mathrm{pH}$ was higher in normocapnic rats than in hypercapnic rats $(8.08 \pm 0.05$ and $7.90 \pm 0.02$, respectively, $P<0.005)$ while urine bicarbonate concentration was not significantly different. GFR did not change significantly in either group while plasma sodium and plasma bicarbonate increased in both groups.

\section{Effect of alkalinization of the urine on urinary $\mathrm{pCO}_{2}$ in} rats not infused with carbonic anhydrase (Table IV)

In the set of experiments presented in Table I, hypercapnia was induced in normocapnic rats that were excreting an alkaline urine and, therefore, had a high urine $\mathrm{pCO}_{2}$. Thus, the additional rise in urinary $\mathrm{pCO}_{2}$ that occurred in these rats could have been the result of abruptly raising the blood $\mathrm{pCO}_{2}$ rather than the consequence of alkalinizing the urine. In the following set of experiments, sodium bicarbonate was infused into hypercapnic rats that were excreting a urine with low bicarbonate content. In hypercapnic rats (group IIa) in which sodium bicarbonate infusion resulted in a high blood $\mathrm{pH}$, urinary $\mathrm{pCO}_{2}$ rose from $58 \pm 6.3$ to $98 \pm 4.9 \mathrm{mmHg}(P<0.005)$ in the absence of any significant change in blood $\mathrm{pCO}_{2}$. This rise in urinary $\mathrm{pCO}_{2}$ was therefore virtually identical to the rise in $\mathrm{U}-\mathrm{B} \mathrm{pCO}_{2}$ (from $-28 \pm 4.7$ to $15 \pm 4.0 \mathrm{mmHg}$ ). The urinary $\mathrm{pCO}_{2}$ achieved under these conditions was comparable to that of rats with moderate (group Ia) and severe hypercapnia (group $\mathrm{Ib}$ ) in which blood $\mathrm{pCO}_{2}$ was increased after alkalinization of the urine (compare Table IV with Table I). Blood pH after bicarbonate loading was also not significantly different (7.55 $\pm 0.02,7.58 \pm 0.01$, and $7.53 \pm 0.02$ in groups $\mathrm{Ia}, \mathrm{Ib}$, and IIa, respectively). Plasma sodium was higher in the hypercapnic rats presented in Table I (groups Ia and Ib) than in those presented in Table IV (group IIa). GFR fell significantly in groups Ia and Ib but not in group IIa, probably because the duration of the experiment was longer in groups Ia and $\mathrm{Ib}$.

In normocapnic control rats (group IIb), urinary $\mathrm{pCO}_{2}$ increased from $37 \pm 3.2$ to $79 \pm 2.6 \mathrm{mmHg}$. Hence, the increment in urinary $\mathrm{pCO}_{2}$ elicited by bicarbonate infusion while blood $\mathrm{pCO}_{2}$ was kept constant (thereafter to be referred to as $\triangle \mathrm{pCO}_{2}$ ) was almost identical in hypercapnic rats (group IIa) and normocapnic rats $(40 \pm 7.2$ and $42 \pm 4.6 \mathrm{mmHg}$, respectively). After bicarbonate loading, urinary $\mathrm{pCO}_{2}$ was higher in hypercapnic rats than in controls $(98 \pm 4.9$ and $79 \pm 2.6 \mathrm{mmHg}, P$ $<0.001$ ), but the $\mathrm{U}-\mathrm{B} \mathrm{pCO}_{2}$ was lower in hypercapnic rats than in controls $(15 \pm 4.0$ and $39 \pm 2.5 \mathrm{mmHg}, P<0.001)$.

In hypercapnic rats (group IV) in which bicarbonate infusion resulted in a normal blood $\mathrm{pH}(7.38 \pm 0.01)$, urinary $\mathrm{pCO}_{2}$ increased from $55 \pm 6.9$ to $125 \pm 3.6 \mathrm{mmHg}, P<0.001$. Thus, the $\Delta \mathrm{pCO}_{2}$ of these rats $(70 \pm 5.6 \mathrm{mmHg})$ was greater than that observed in normocapnic rats $(42 \pm 4.6 \mathrm{mmHg}$ ) (Fig. 3, left). It was also greater $(P<0.005)$ than that of hypercapnic rats $(40 \pm 7.2 \mathrm{mmHg}$ ) with a higher blood $\mathrm{pH}$ (group IIa). The

Table II. Effect of Acute Respiratory Acidosis (Group IIa) on Acid Excretion

\begin{tabular}{|c|c|c|c|c|c|c|c|c|c|c|c|c|}
\hline & \multirow[b]{2}{*}{ GFR } & \multirow[b]{2}{*}{$\mathbf{v}$} & \multicolumn{3}{|l|}{ Blood } & \multirow{2}{*}{$\begin{array}{l}\text { Plasma } \\
\text { K }\end{array}$} & \multirow{2}{*}{$\begin{array}{l}\text { Plasma } \\
\mathrm{PO}_{4}\end{array}$} & \multirow[b]{2}{*}{$\mathrm{UPO}_{4} \times \mathrm{V}$} & \multirow{2}{*}{$\begin{array}{l}\text { Urine } \\
\text { pH }\end{array}$} & \multirow[b]{2}{*}{ TA } & \multirow[b]{2}{*}{$\mathrm{NH}_{4}$} & \multirow[b]{2}{*}{ Net acid } \\
\hline & & & $\mathrm{pH}$ & $\mathrm{pCO}_{2}$ & $\mathrm{HCO}_{3}$ & & & & & & & \\
\hline & $\mathrm{ml} / \mathrm{min}$ & $\mathrm{ml} / \mathrm{min}$ & & $m m H g$ & meq/liter & meq/liter & $\mathrm{mmol} / \mathrm{liter}$ & $\mu \mathrm{mol} / \mathrm{min}$ & & $\mu \mathrm{mol} / \mathrm{min}$ & $\mu \mathrm{mol} / \mathrm{min}$ & $\mu \mathrm{mol} / \mathrm{min}$ \\
\hline Prehypercapnia & 3.4 & 0.01 & 7.42 & 40 & 25 & 3.5 & 2.0 & 0.1 & 6.5 & 0.2 & 0.4 & 0.5 \\
\hline$(n=7)$ & \pm 0.4 & \pm 0.03 & \pm 0.01 & \pm 1.5 & \pm 1.5 & \pm 0.2 & \pm 0.1 & \pm 0.05 & \pm 0.2 & \pm 0.05 & \pm 0.1 & \pm 0.2 \\
\hline$P$ value & NS & NS & 0.001 & 0.001 & NS & 0.01 & NS & 0.01 & 0.05 & 0.005 & NS & 0.005 \\
\hline Hypercapnia & 2.6 & 0.02 & 7.13 & 84 & 28 & 4.4 & 2.7 & 1.2 & 5.7 & 1.3 & 0.4 & 1.7 \\
\hline (1st h) & \pm 0.3 & \pm 0.02 & \pm 0.02 & \pm 2.2 & \pm 1.3 & \pm 0.3 & \pm 0.1 & \pm 0.3 & \pm 0.09 & \pm 0.2 & \pm 0.05 & \pm 0.2 \\
\hline$P$ value & NS & 0.05 & NS & NS & NS & NS & NS & 0.01 & NS & 0.005 & 0.05 & 0.005 \\
\hline Hypercapnia & 3.0 & 0.04 & 7.14 & 86 & 29 & 4.4 & 2.7 & 2.7 & 5.8 & 2.5 & 1.0 & 3.4 \\
\hline (2nd h) & \pm 0.2 & \pm 0.07 & \pm 0.02 & \pm 1.7 & \pm 1.2 & \pm 0.1 & \pm 0.09 & \pm 0.5 & \pm 0.06 & \pm 0.1 & \pm 0.2 & \pm 0.3 \\
\hline * & NS & 0.02 & 0.001 & 0.001 & NS & 0.01 & 0.01 & 0.005 & 0.025 & 0.001 & 0.05 & 0.001 \\
\hline
\end{tabular}

\footnotetext{
* Statistical analysis ( $P$ value) between hypercapnia ( 2 nd $h$ ) and prehypercapnia.
} 


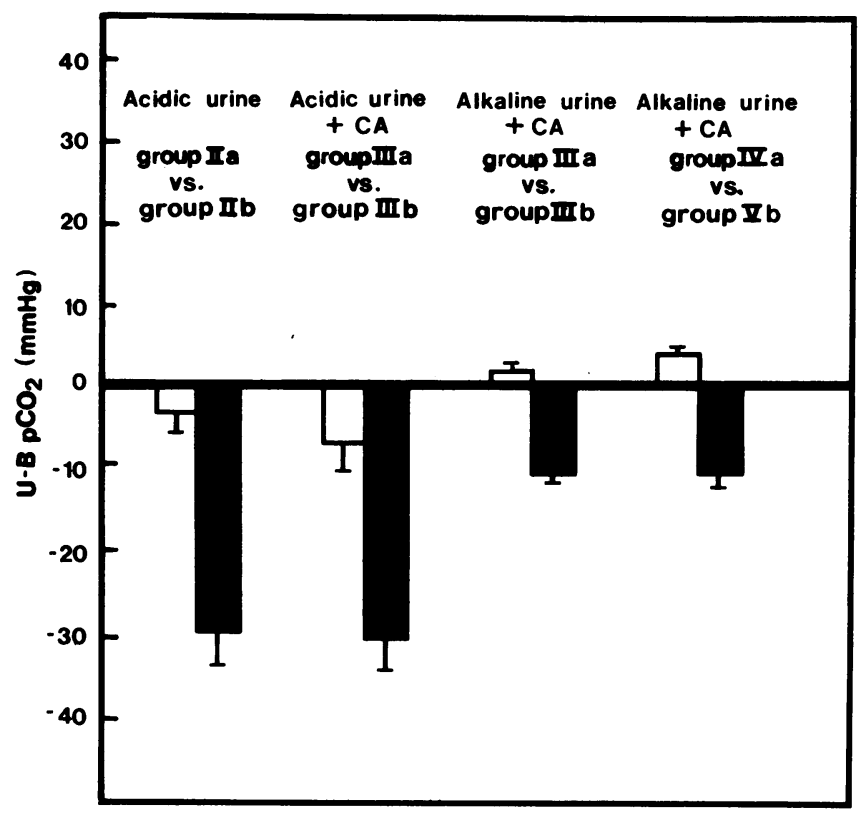

Figure 2. The $\mathrm{U}-\mathrm{B} \mathrm{pCO}$ of hypercapnic rats (groups IIa, IIIa, and IVa) is compared with that of normocapnic control rats (groups IIb, IIIb, and Va). The U-B pCO ${ }_{2}$ of hypercapnic rats was lower than that of normocapnic control rats when the urine was acid (with and without carbonic anhydrase infusion) and when it was alkalinized in the face of a continuous carbonic anhydrase (CA) infusion. $\square$, control; $\mathbf{\square}$, hypercapnia.

$\mathrm{U}-\mathrm{B} \mathrm{pCO}_{2}$ of group IV hypercapnic rats $(39 \pm 3.7 \mathrm{mmHg})$ was significantly higher than that of group IIa hypercapnic rats $(15 \pm 4.0 \mathrm{mmHg})$ and not significantly different than that of normocapnic controls (group IIb) $(39 \pm 2.5 \mathrm{mmHg})$. These differences in urine $\mathrm{pCO}_{2}$ and $\mathrm{U}-\mathrm{B} \mathrm{pCO}_{2}$ were observed in the face of a comparable increase in urine bicarbonate concentration in the three groups studied (Fig. 4). Plasma sodium also increased to a comparable level in the three groups. Plasma K was higher in hypercapnic rats than in controls.

Effect of carbonic anhydrase infusion on urine $\mathrm{pCO}_{2}$ in rats excreting an alkaline urine (Table $V$ )

In normocapnic control rats (group $\mathrm{Va}$ ), carbonic anhydrase infusion resulted in a fall in urine $\mathrm{pCO}_{2}$ (from $73 \pm 1.9$ to $43 \pm 1.3 \mathrm{mmHg}, P<0.001$ ) while urine bicarbonate concentration did not change significantly. Consequently, urine $\mathrm{pH}$ increased (from $7.87 \pm 0.03$ to $8.04 \pm 0.04, P<0.02$ ). In hypercapnic rats (group IVa), the infusion of carbonic anhydrase also resulted in a fall in urine $\mathrm{pCO}_{2}$ (from $122 \pm 5.7$ to $77 \pm 2.2$ $\mathrm{mmHg}, P<0.001$ ), while urine bicarbonate concentration did not change and urine $\mathrm{pH}$ increased (from $7.65 \pm 0.03$ to $7.85 \pm 0.03, P<0.005)$. The fall in urine $\mathrm{pCO}_{2}$ elicited by carbonic anhydrase infusion was greater in hypercapnic rats than in normocapnic controls $(-45 \pm 4.3$ and $-30 \pm 2.6 \mathrm{mmHg}$, respectively, $P<0.02$ ) (Fig. 3, right).

Nonbicarbonate buffer capacity was not significantly different between normocapnic and hypercapnic rats either before $(2.4 \pm 0.3$ and $2.3 \pm 0.6 \mathrm{meq} /$ liter per $\mathrm{pH}$ unit, respectively) or after carbonic anhydrase infusion $(2.5 \pm 0.5$ and $3.9 \pm 2.3 \mathrm{meq} /$ liter per pH unit, respectively).

Carbonic anhydrase activity in the urine was not significantly different between hypercapnic and normocapnic rats
(275 \pm 96 vs. $362 \pm 103 \mu \mathrm{g} / \mathrm{ml}$, respectively). Likewise, the excretion of this enzyme was not significantly different between the two groups $(31 \pm 8.3$ vs. $23 \pm 4.0 \mu \mathrm{g} / \mathrm{min}$, respectively). Carbonic anhydrase infusion was associated with a significant fall in GFR and urine flow in both hypercapnic and normocapnic rats. Neither parameter, however, was significantly different between hypercapnic and normocapnic rats.

In time control rats (group $\mathrm{Vb}$ ) GFR also fell significantly, but urine, $\mathrm{pCO}_{2}$, and $\mathrm{U}-\mathrm{B} \mathrm{pCO}_{2}$ did not. The fall in GFR was likely the result of the prolonged duration of this experiment. Nonbicarbonate buffer capacity in the time control group was not significantly different than that of hypercapnic (group IVa) and normocapnic rats (group Va) infused with carbonic anhydrase.

After carbonic anhydrase infusion, the urine $\mathrm{pCO}_{2}$ of hypercapnic rats (group IVa) fell to a level lower than that of the blood $(77 \pm 2.2$ and $86 \pm 0.9 \mathrm{mmHg}$, respectively, $P$ $<0.025$ ), while that of normocapnic rats (group Va) did not $(43 \pm 1.3$ and $40 \pm 1.0 \mathrm{mmHg}$, respectively). Thus, the relationship between urine $\mathrm{pCO}_{2}$ and blood $\mathrm{pCO}_{2}$ was virtually identical to that observed in hypercapnic (group IIIa) and normocapnic rats (group IIIb) in which the infusion of carbonic anhydrase antedated the infusion of bicarbonate (Fig. 2). As anticipated, the urinary $\mathrm{pCO}_{2}$ achieved in both hypercapnic and normocapnic rats infused with sodium bicarbonate and carbonic anhydrase was markedly lower than that observed when this enzyme was not administered (compare Tables III and $\mathrm{V}$ with Table IV).

\section{Discussion}

This study demonstrates a clear dissociation between urine $\mathrm{pCO}_{2}$ and blood $\mathrm{pCO}_{2}$ during acute hypercapnia. In normocapnic rats excreting a highly alkaline urine, induction of severe hypercapnia resulted in a fall in the $\mathrm{U}-\mathrm{B} \mathrm{pCO}_{2}$ gradient despite an increase in urine $\mathrm{pCO}_{2}$ (group Ia, Table I). According to current views $(9,16-29,36)$, the finding that the U-B $\mathrm{pCO}_{2}$ achieved during bicarbonate loading is lower in hypercapnic rats than in normocapnic rats (Tables I and IV) requires the conclusion that collecting duct $\mathrm{H}^{+}$secretion is decreased by hypercapnia. In fact, such a conclusion was recently reached by another group of investigators who noted that the U-B $\mathrm{pCO}_{2}$ gradient of hypercapnic dogs infused with sodium bicarbonate was lower than normal (23).

That the low $\mathrm{U}-\mathrm{B} \mathrm{pCO}_{2}$ observed during bicarbonate loading reflects decreased collecting duct $\mathrm{H}^{+}$secretion during hypercapnia, however, is not likely correct. The urine $\mathrm{pCO}_{2}$ of hypercapnic rats was higher than that of normocapnic rats, a finding that could be interpreted as indicative of enhanced collecting duct $\mathrm{H}^{+}$secretion in hypercapnic rats (i.e., the opposite interpretation of that portrayed by the $\mathrm{U}-\mathrm{B} \mathrm{pCO}_{2}$ gradient). Alternatively, it could be argued that the higher urine $\mathrm{pCO}_{2}$ observed in hypercapnic rats was purely the result of their higher blood $\mathrm{pCO}_{2}$. The following findings, however, mitigate against the latter possibility.

First, rats with moderate hypercapnia (group Ib) exhibited a urinary $\mathrm{pCO}_{2}$ virtually identical to that of rats with severe hypercapnia (group Ia) in the face of a comparable urine bicarbonate concentration (Fig. 1). This finding indicates that the $\mathrm{U}-\mathrm{B} \mathrm{pCO}_{2}$ was influenced by changes in systemic blood $\mathrm{pCO}_{2}$ rather than by changes in urinary $\mathrm{pCO}_{2}$ generation. Second, urinary $\mathrm{pCO}_{2}$ did not increase to the level prevailing in the blood in hypercapnic animals excreting a urine of low 


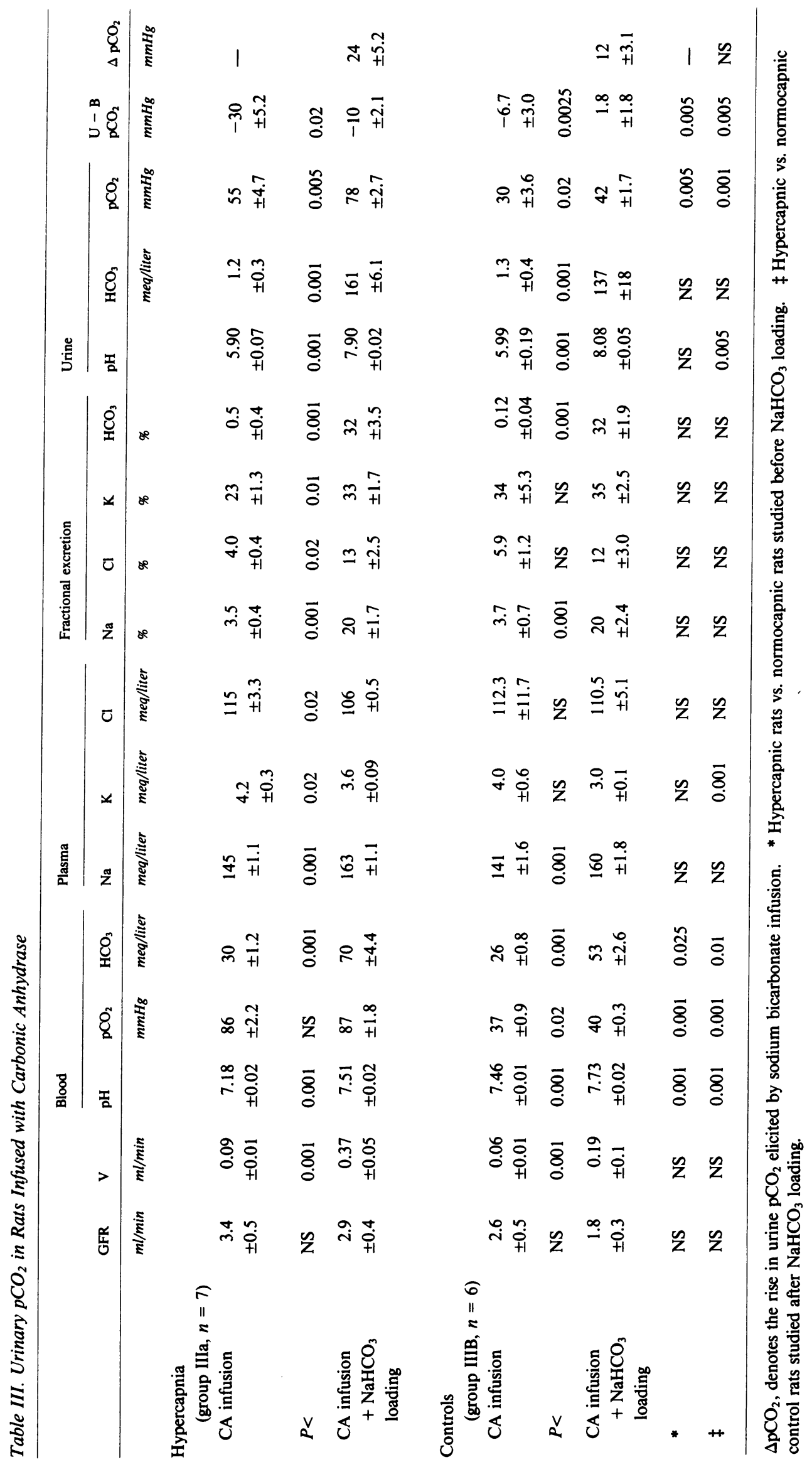




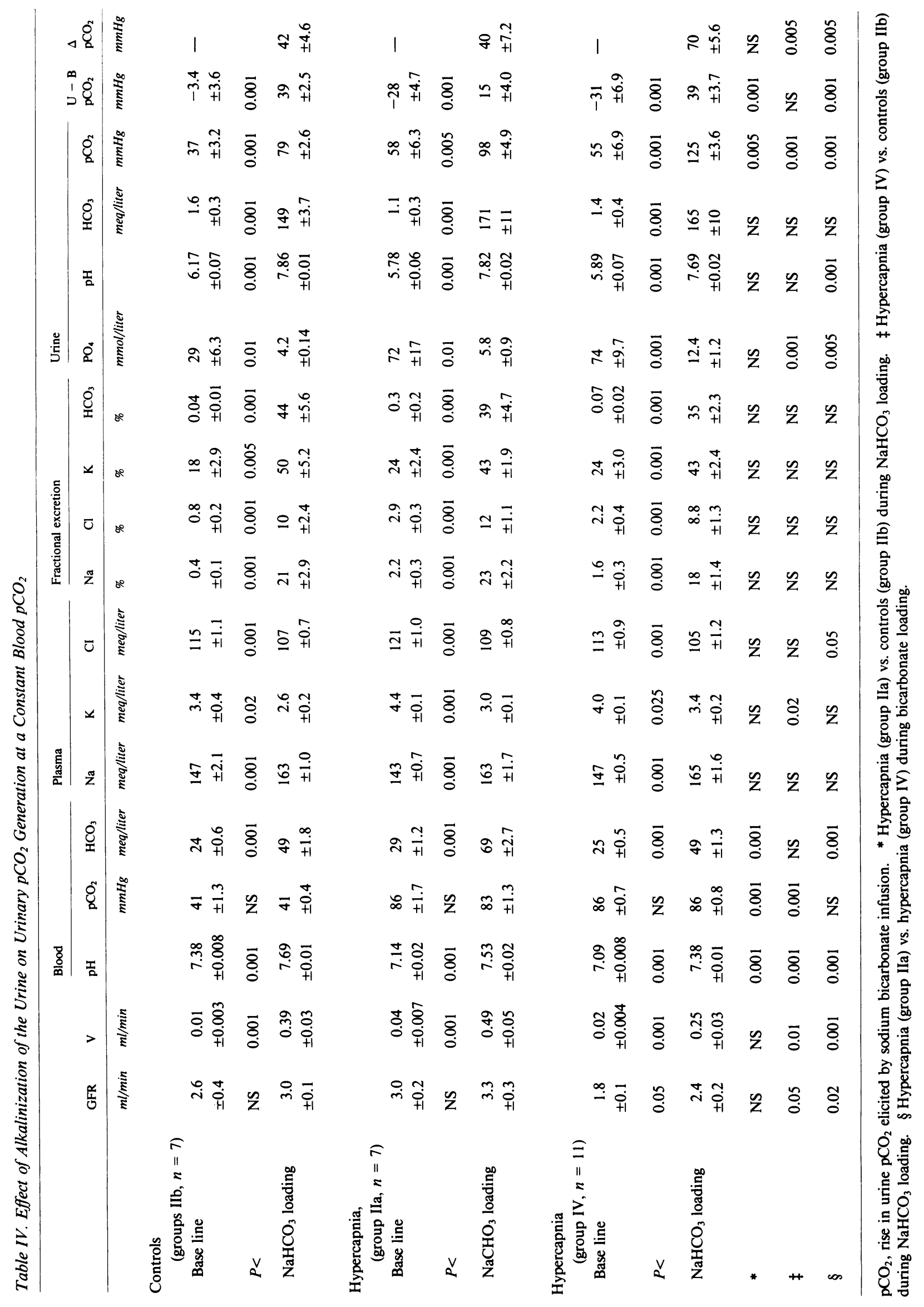




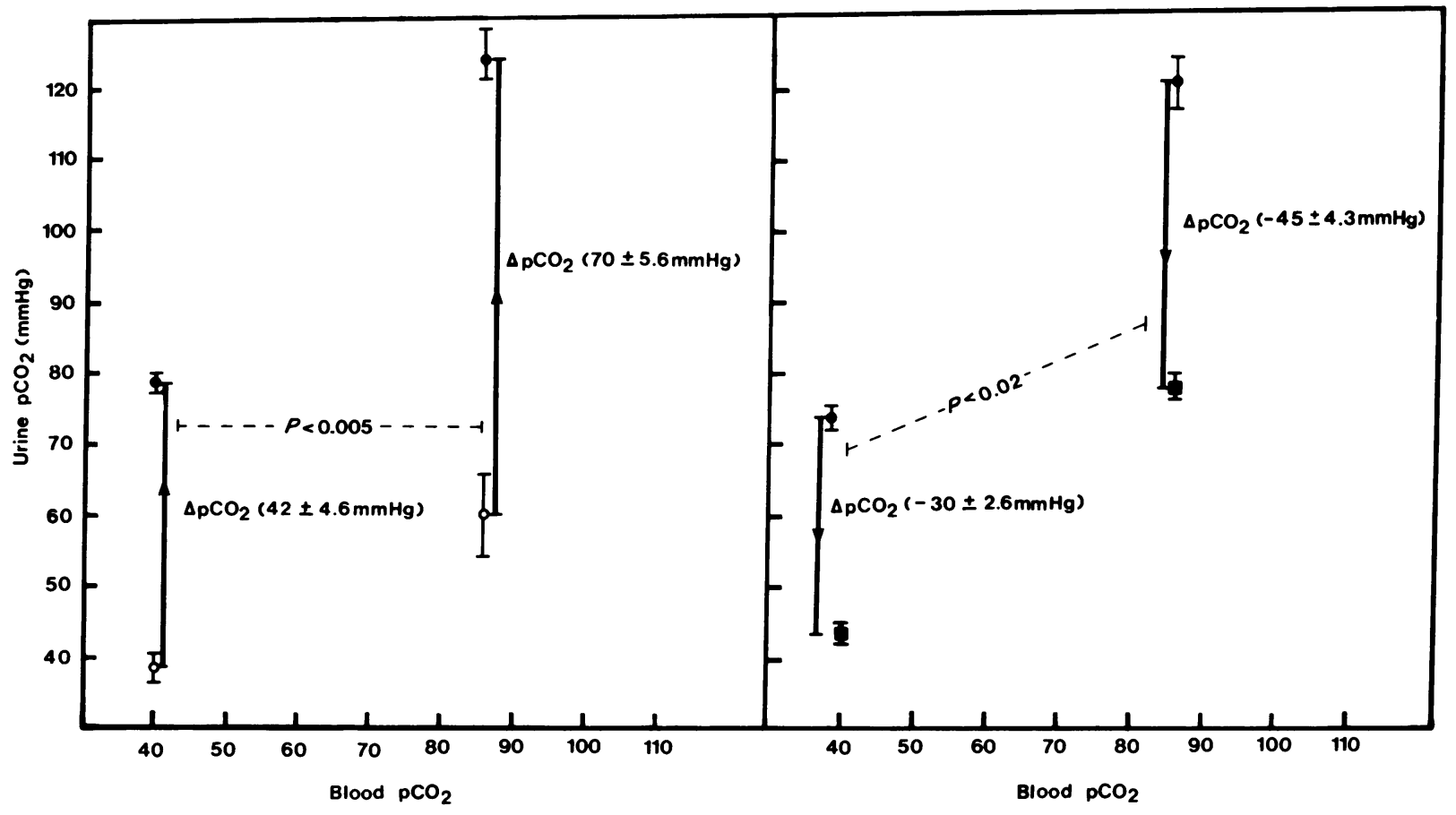

Figure 3. The relationship of urine $\mathrm{pCO}_{2}$ to blood $\mathrm{pCO}_{2}$ during normocapnia and hypercapnia. The left panel depicts the increase in urine $\mathrm{pCO}_{2}$ elicited by sodium bicarbonate loading (i.e., the $\triangle \mathrm{pCO}_{2}$ ) in normocapnic rats (group IIb) and hypercapnic rats (group IV). Open circles denote urine $\mathrm{pCO}_{2}$ when the urine was acid; closed circles denote the urine $\mathrm{pCO}_{2}$ achieved during bicarbonate loading. The $\Delta \mathrm{pCO}_{2}$ was significantly higher in hypercapnic rats than in normocapnic controls $(P<0.005)$. The right panel depicts the fall in urine $\mathrm{pCO}_{2}\left(-\Delta \mathrm{pCO}_{2}\right)$ caused by carbonic anhydrase infusion to normocapnic rats (group $\mathrm{Va}$ ) and hypercapnic rats (group IVa). Closed circles denote urine $\mathrm{pCO}_{2}$ in an alkaline urine. Closed boxes denote that urine $\mathrm{pCO}_{2}$ was measured during carbonic anhydrase infusion. The fall in urine $\mathrm{pCO}_{2}$ elicited by carbonic anhydrase infusion was significantly higher in hypercapnic rats than in normocapnic controls $(P<0.02)$.

and in the presence of large urinary bicarbonate concentrations. Thus, factors other than equilibration between systemic blood $\mathrm{pCO}_{2}$ and renal $\mathrm{pCO}_{2}$ determine, at least in part, the urine $\mathrm{pCO}_{2}$ in hypercapnic rats (see below).

Having established that the urinary $\mathrm{pCO}_{2}$ of hypercapnic rats is lower than systemic blood $\mathrm{pCO}_{2}$ we sought to determine the effect of alkalinization of the urine on urinary $\mathrm{pCO}_{2}$ generation when blood $\mathrm{pCO}_{2}$ was kept constant. We reasoned that if blood $\mathrm{pCO}_{2}$ were not allowed to change the increment in urinary $\mathrm{pCO}_{2}$ observed in response to sodium bicarbonate loading (i.e., the $\Delta \mathrm{pCO}_{2}$ ), it would provide an indirect qualitative measurement of collecting duct $\mathrm{H}^{+}$secretion. The $\triangle \mathrm{pCO}_{2}$ of hypercapnic rats with a high blood pH (group IIa) was comparable to that of normocapnic rats with a high blood $\mathrm{pH}$ (group IIb) (Table IV). The $\triangle \mathrm{pCO}_{2}$ of hypercapnic rats with a normal blood pH (group IV) was higher than that of normocapnic rats (Fig. 3, left), and than that of hypercapnic rats with a high blood pH (group IIa) (Table IV). The $\mathrm{U}-\mathrm{B} \mathrm{pCO}_{2}$ achieved by hypercapnic rats with a high blood pH (group Ila), however, was again lower than that of normocapnic rats (group IIb) $(15 \pm 4.0$ and $39 \pm 1.5 \mathrm{mmHg}$, respectively), while that of hypercapnic rats with a normal blood $\mathrm{pH}$ (group IV) was the same $(39 \pm 3.7$ and $39 \pm 2.5 \mathrm{mmHg}$, respectively).

Urinary bicarbonate concentration, a major determinant of urinary $\mathrm{pCO}_{2}$ generation (13-30), increased to a comparable level in both groups of hypercapnic rats and in normocapnic controls (Fig. 4). Since blood $\mathrm{pCO}_{2}$ was not allowed to change, 


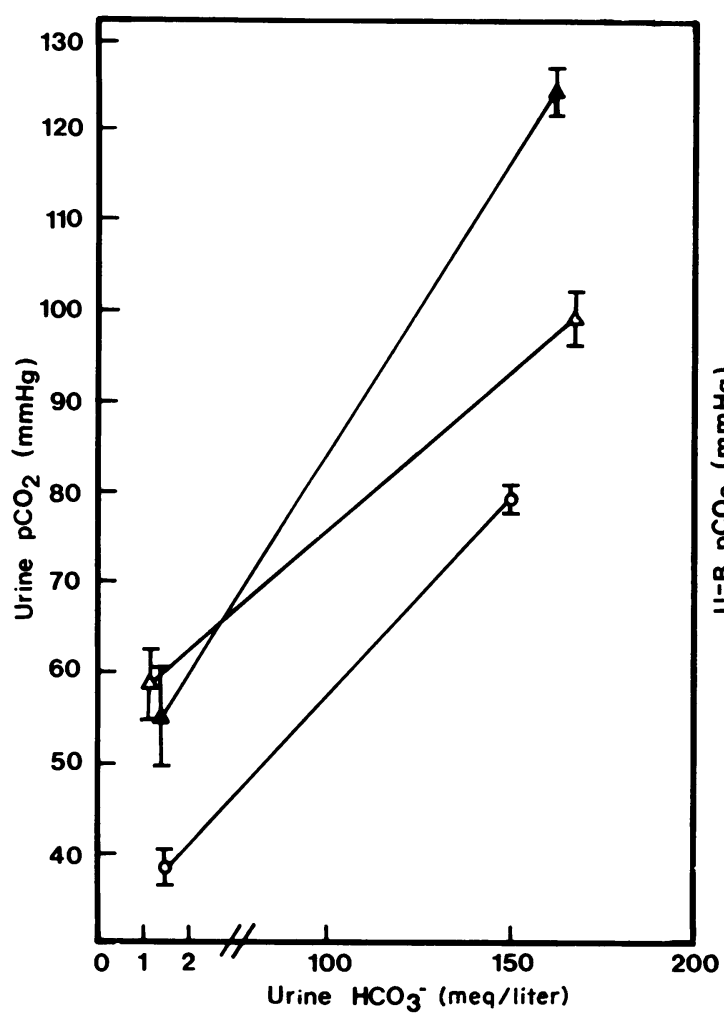

Figure 4. Urine $\mathrm{pCO}_{2}$ as a function of urine bicarbonate concentration (left) and $\mathrm{U}-\mathrm{B} \mathrm{pCO}$ as a function of urine bicarbonate concentration (right). At a comparably high urine bicarbonate concentration, rats with hypercapnia and a normal blood pH (group IV) (closed triangles) achieved a urine $\mathrm{pCO}_{2}$ significantly higher than that

the rise in urine $\mathrm{pCO}_{2}$ was the consequence, at least in part, of collecting duct $\mathrm{H}^{+}$secretion into a bicarbonate-rich urine and not the consequence of equilibration between intrarenal and systemic blood $\mathrm{pCO}_{2}$.

Urine $\mathrm{pCO}_{2}$ and its derivatives as indices of distal acidifcation. The possible pitfalls of the urine $\mathrm{pCO}_{2}$ and its derivatives as markers of collecting duct hydrogen ion secretion can be summarized as follows:

(a) $\mathrm{U}-\mathrm{B} \mathrm{pCO}_{2}$ during bicarbonate loading. The use of the $\mathrm{U}-\mathrm{B} \mathrm{pCO}_{2}$ observed in a highly alkaline urine as an index of collecting duct $\mathrm{H}^{+}$secretion requires that during bicarbonate loading, systemic blood $\mathrm{pCO}_{2}$ be similar to that of medullary blood. DuBose (9), however, has recently demonstrated that in a highly alkaline urine the $\mathrm{pCO}_{2}$ in the papillary collecting duct and adjacent vasa recta is markedly higher than that of the systemic blood (9). Thus, in normocapnic subjects infused with bicarbonate, intrarenal blood $\mathrm{pCO}_{2}$ and systemic blood $\mathrm{pCO}_{2}$ dissociate. Since the rise in urine $\mathrm{pCO}_{2}$ in an alkaline urine occurs in the collecting duct and is, therefore, associated with a rise in vasa recta $\mathrm{pCO}_{2}$, the use of the $\mathrm{U}-\mathrm{B} \mathrm{pCO}_{2}$ serves no purpose because systemic blood $\mathrm{pCO}_{2}$ is not a reflection of intrarenal blood $\mathrm{pCO}_{2}(30)$. This fact, in our view, invalidates the use of the $\mathrm{U}-\mathrm{B} \mathrm{pCO}_{2}$ gradient in a highly alkaline urine as an index of distal $\mathrm{H}^{+}$secretion even during normocapnia. This is not to say that the conclusions derived from numerous studies in normocapnic subjects using the $\mathrm{U}-\mathrm{B} \mathrm{pCO}_{2}$ gradient as a marker of distal acidification need to be altered. When urinary $\mathrm{pCO}_{2}$ and blood $\mathrm{pCO}_{2}$ are about the same before bicarbonate loading (as is usually the case of hypercapnic rats (group IIa) (open triangles) and normocapnic rats (group IIb) (open circles) that were alkalemic. The $\mathrm{U}-\mathrm{B} \mathrm{pCO}_{2}$ of group IIa rats was lower, while that of group IV was equal to that of normocapnic control rats (group IIb) with a comparably high urine bicarbonate concentration.

during normocapnia), the rise in urinary $\mathrm{pCO}_{2}$ elicited by sodium bicarbonate infusion is equivalent to the $\mathrm{U}-\mathrm{B} \mathrm{pCO}_{2}$ achieved under this condition (e.g., normocapnic rats, Table IV). Therefore, both parameters yield the same information in regards to the ability to generate $\mathrm{CO}_{2}$ as a result of collecting duct $\mathrm{H}^{+}$secretion. When blood $\mathrm{pCO}_{2}$ and urine $\mathrm{pCO}_{2}$ are widely different, however, the $\mathrm{U}-\mathrm{B} \mathrm{pCO}_{2}$ gradient achieved during bicarbonate loading becomes an artifact that gives no physiological information about collecting duct $\mathrm{H}^{+}$secretion. The artifactual nature of the $\mathrm{U}-\mathrm{B} \mathrm{pCO}_{2}$ gradient is illustrated by our studies during hypercapnia, where it clearly underestimates distal $\mathrm{H}^{+}$secretion (Table IV, Fig. 4). This situation is the opposite of hypocapnia, where the $\mathrm{U}-\mathrm{B} \mathrm{pCO}_{2}$ gradient can overestimate collecting duct $\mathrm{H}^{+}$secretion (44).

(b) Urine $\mathrm{pCO}_{2}$ after bicarbonate loading. To take into account the relationship between urine $\mathrm{pCO}_{2}$ and blood $\mathrm{pCO}_{2}$ that prevailed before administration of sodium bicarbonate, we used the $\Delta \mathrm{pCO}_{2}$ as an index of collecting duct $\mathrm{H}^{+}$secretion (Table IV, Fig. 3, left). Blood $\mathrm{pCO}_{2}$ was no longer a variable because it was not allowed to change, and the base-line urine $\mathrm{pCO}_{2}$ (i.e., the $\mathrm{pCO}_{2}$ of an acid urine) was known. Thus, the $\Delta \mathrm{pCO}_{2}$ is appropriate as a qualitative index of collecting duct $\mathrm{H}^{+}$secretion, in that it integrates the effects of both an acid and a highly alkaline urine on intrarenal $\mathrm{CO}_{2}$ generation while it eliminates the blood $\mathrm{pCO}_{2}$ as a variable. If the $\Delta \mathrm{pCO}_{2}$ were the best way to express the relationship between urinary $\mathrm{pCO}_{2}$ generation and collecting duct $\mathrm{H}^{+}$secretion, one would have to conclude that collecting duct $\mathrm{H}^{+}$secretion was normal in 


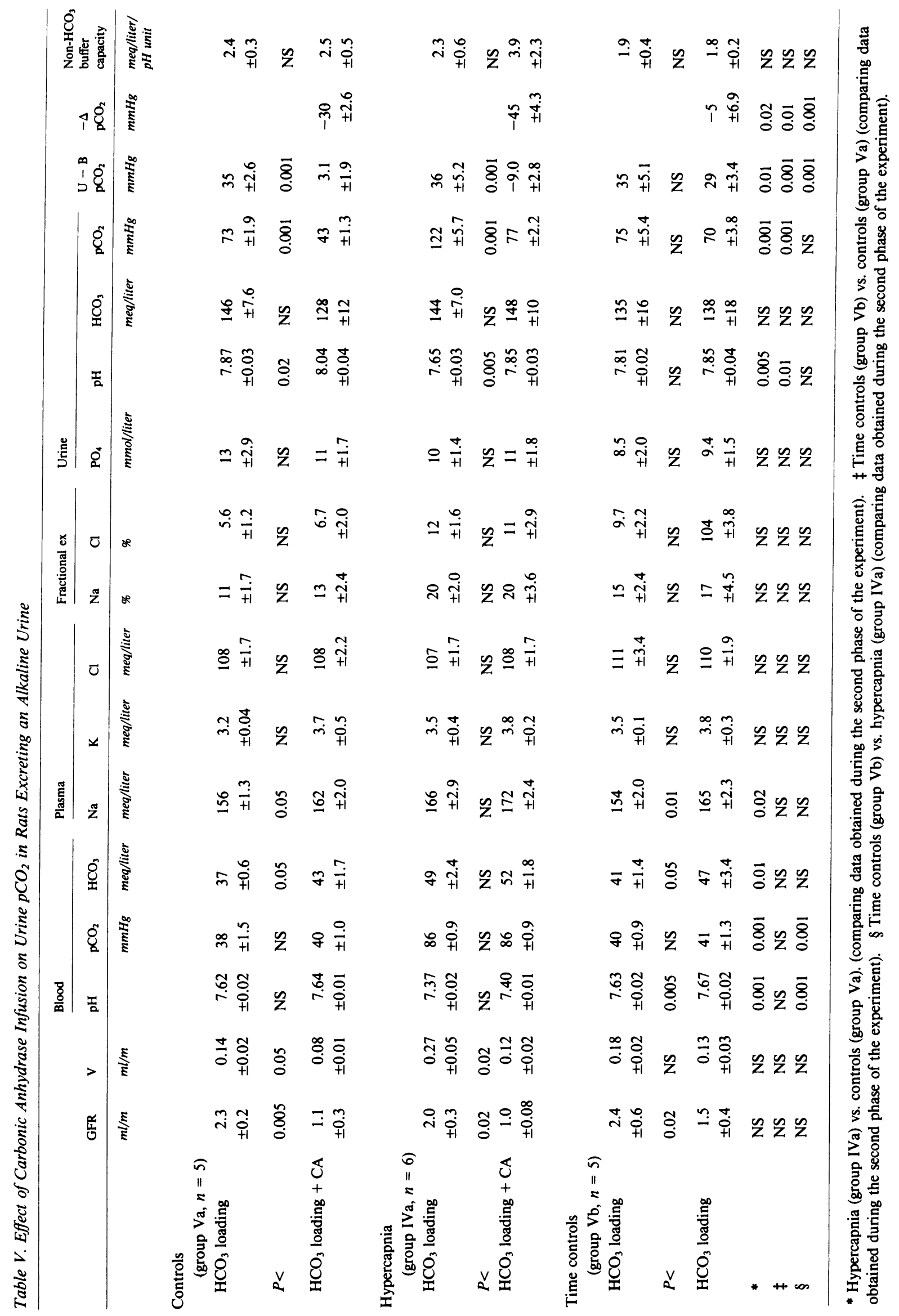


hypercapnic rats that were alkalemic (group IIa) and enhanced in hypercapnic rats that were not alkalemic (group IV). This conclusion requires validation by measuring collecting duct $\mathrm{pCO}_{2}$ and vasa recta $\mathrm{pCO}_{2}$ before and after bicarbonate loading during sustained hypercapnia. While this information is currently not available, it is now known that in normocapnic rats, vasa recta $\mathrm{pCO}_{2}$ and papillary collecting duct $\mathrm{pCO}_{2}$ increase in a one to one ratio when the urine is highly alkaline (9). There is no a priori reason to believe that such a relationship does not exist during hypercapnia.

The $\Delta \mathrm{pCO}_{2}$ may be problematic, in that a number of variables (blood $\mathrm{pH}$, plasma sodium, plasma potassium, volume status, medullary blood flow rate, etc.) change during bicarbonate diuresis as compared with base-line conditions. In this regard, the end point urine $\mathrm{pCO}_{2}$ observed under identical conditions of bicarbonate diuresis, urine flow rate, and volume status is a more suitable marker of collecting duct $\mathrm{H}^{+}$secretion than the $\Delta \mathrm{pCO}_{2}$. If one were to use the end-point urine $\mathrm{pCO}_{2}$, one would have to conclude that collecting duct $\mathrm{H}^{+}$secretion was enhanced in both groups of hypercapnic rats because the end-point urine $\mathrm{pCO}_{2}$ was higher than that of normocapnic controls (Fig. 4). It is readily apparent, however, that the urine $\mathrm{pCO}_{2}$ (i.e., that observed in a highly alkaline urine) fails to take into account the fact that the $\mathrm{pCO}_{2}$ prevailing in the urine of hypercapnic animals before bicarbonate loading is higher than that of normocapnic rats. Thus, during hypercapnia, the end point urine $\mathrm{pCO}_{2}$ observed after bicarbonate loading is uncertain as a marker of collecting duct $\mathrm{H}^{+}$secretion because it could overestimate it as opposed to the $\mathrm{U}-\mathrm{B} \mathrm{pCO}_{2}$, which underestimates it.

We attempted to equalize urine $\mathrm{pCO}_{2}$ and blood $\mathrm{pCO}_{2}$ in hypercapnic rats by alkalinizing the urine in the presence of carbonic anhydrase infusion. We reasoned that the rise in urinary $\mathrm{pCO}_{2}$ attributable to $\mathrm{H}^{+}$secretion into a bicarbonaterich urine would be dissipated by accelerating carbonic acid dehydration, and that urinary $\mathrm{pCO}_{2}$ and blood $\mathrm{pCO}_{2}$ would be approximately the same. Urinary $\mathrm{pCO}_{2}$ was about that of the blood in normocapnic rats but not in hypercapnic rats (Tables III and V, Fig. 2). The finding of a urinary $\mathrm{pCO}_{2}$ lower than that of the blood in a highly alkaline urine rich in carbonic anhydrase deserves consideration. We think that accelerated consumption of $\mathrm{CO}_{2}$ within collecting duct cells accounts for lowering of tubular $\mathrm{CO}_{2}$ (and final urine $\mathrm{CO}_{2}$ ) below systemic blood levels during hypercapnia. $\mathrm{CO}_{2}$ is likely consumed and bicarbonate regenerated because of enhanced secretion of $\mathrm{H}^{+}$, which under these conditions is titrated by bicarbonate and by nonbicarbonate buffer. The titration of $\mathrm{H}^{+}$ by bicarbonate, in the presence of carbonic anhydrase, does not increase urine $\mathrm{pCO}_{2}$ because of accelerated carbonic acid dehydration; the titration of $\mathrm{H}^{+}$by nonbicarbonate buffer consumes $\mathrm{CO}_{2}$ in the process of bicarbonate regeneration and lowers urine $\mathrm{CO}_{2}$. These two processes likely occur in both hypercapnic and normocapnic rats. That urine $\mathrm{pCO}_{2}$ is lower than that prevailing in the blood in hypercapnic rats but not in normocapnic rats requires either enhanced collecting duct $\mathrm{H}^{+}$secretion or excess nonbicarbonate buffer in the hypercapnic animals. The urinary nonbicarbonate buffer capacity was comparable between hypercapnic and normocapnic rats (Table V), which suggests that enhanced collecting duct $\mathrm{H}^{+}$secretion was, at least in part, the cause of tubular $\mathrm{CO}_{2}$ removal during hypercapnia.

The basic principle in using the urinary $\mathrm{pCO}_{2}$ in a highly alkaline urine as a marker of distal acidification is to estimate the amount of $\mathrm{pCO}_{2}$ generated from $\mathrm{H}^{+}$secretion and titration of bicarbonate buffer in the face of delayed carbonic acid dehydration (i.e., in the absence of carbonic anhydrase in the lumen of the distal nephron). In this regard, the difference in urine $\mathrm{pCO}_{2}$ obtained in a highly alkaline urine not containing carbonic anhydrase and in an equally alkaline urine containing carbonic anhydrase should provide the best possible estimate of $\mathrm{pCO}_{2}$ generated from $\mathrm{H}^{+}$secretion and titration of bicarbonate buffer. To attack this issue, we gave carbonic anhydrase to hypercapnic and normocapnic rats that were excreting an alkaline urine (Table $\mathrm{V}$ ). This maneuver resulted in a greater fall in urine $\mathrm{pCO}_{2}$ (i.e., $-\Delta \mathrm{pCO}_{2}$ ) in hypercapnic rats than in normocapnic rats (Fig. 3, right). This clearly demonstrates that the amount of $\mathrm{pCO}_{2}$ generated in the face of delayed carbonic acid dehydration (i.e., before carbonic anhydrase infusion) was greater in these hypercapnic rats thap in controls, a finding which denotes enhanced collecting duct $\mathrm{H}^{+}$secretion. Blood pH was normal in the hypercapnic rats and alkalemic in normocapnic rats. Since changes in serosal pH $(21,45,46)$ are known to modulate $\mathrm{H}^{+}$secretion, it seems likely that the difference in urinary $\mathrm{pCO}_{2}$ generation noted between hypercapnic and normocapnic rats was determined by the prevailing blood $\mathrm{pH}$ rather than blood $\mathrm{pCO}_{2}$. This is further suggested by the finding of a higher $\Delta \mathrm{pCO}_{2}$ in hypercapnic rats with a normal blood pH (group IV) than in those with a high blood $\mathrm{pH}$ (group IIa), while blood $\mathrm{pCO}_{2}$ was identical in both groups (Table IV).

(c) Urinary $\mathrm{pCO}_{2}$ before bicarbonate loading. The finding that urinary $\mathrm{pCO}_{2}$ is lower than systemic blood $\mathrm{pCO}_{2}$ in hypercapnic rats excreting an acid urine (Fig. 2, Tables III and IV) also deserves some comment. In an acid urine, secreted $\mathrm{H}^{+}$must react with buffers other than bicarbonate because the amount of filtered bicarbonate reaching the collecting duct is very low. Carbonic acid formation is necessarily low, thereby limiting the amount of $\mathrm{CO}_{2}$ generated from the dehydration of this acid. In keeping with this notion, carbonic anhydrase infusion to hypercapnic rats in which the urine contained little bicarbonate did not result in a urinary $\mathrm{pCO}_{2}$ different from that of hypercapnic rats not infused with the enzyme. In other words, the enzyme had no effect on urinary $\mathrm{pCO}_{2}$ because bicarbonate was virtually absent from the lumen of the collecting duct. Collecting duct $\mathrm{H}^{+}$secretion when luminal bicarbonate is negligible results in the titration of nonbicarbonate buffer, a process that causes consumption of $\mathrm{CO}_{2}$ because $\mathrm{CO}_{2}$ combines with hydroxyl anions in the cell to regenerate bicarbonate.

Note, however, that the mechanism(s) whereby urine $\mathrm{pCO}_{2}$ is lower than that of the blood in animals excreting an acidic urine has never been definitively elucidated. Rector (47) considered several possibilities other than collecting duct $\mathrm{H}^{+}$ secretion. Enhanced bicarbonate reabsorption by a nonhydrogen ion secretory mechanism could lower tubular $\mathrm{CO}_{2}(31,47)$. This is not likely, because the amount of bicarbonate reaching the collecting duct in our experiments was minimal, as judged by the extremely low urinary bicarbonate concentration obtained during acute respiratory acidosis.

Another factor that could lower urine $\mathrm{pCO}_{2}$ is mixing of urine containing excess of nonbicarbonate buffer with a poorly buffered acid urine $(3,47)$. Assuming that the nonbicarbonate buffer in excess during acute respiratory acidosis is phosphate, carbonic acid present in acidic urine will be consumed in the following reaction: $\mathrm{H}_{2} \mathrm{CO}_{3}+\mathrm{Na}_{2} \mathrm{HPO}_{4} \rightarrow \mathrm{NaHCO}_{3}$ $+\mathrm{NaH}_{2} \mathrm{PO}_{4}$. We cannot exclude a role for excess urinary 
phosphate buffer in lowering urine $\mathrm{pCO}_{2}$ below systemic blood $\mathrm{pCO}_{2}$, because urine phosphate concentration was higher in rats with acute respiratory acidosis than in controls. It must be emphasized that the hypothetical role of admixture of heterogeneous urine as a mechanism of lowering tubular $\mathrm{CO}_{2}$ tensions does not negate the role of enhanced $\mathrm{H}^{+}$secretion as the main mechanism responsible for this phenomenon.

It is now known that during acute respiratory acidosis, renal cortical $\mathrm{pCO}_{2}$ exceeds systemic blood $\mathrm{pCO}_{2}$ (36) while inner medullary collecting duct $\mathrm{pCO}_{2}$ is lower than arterial blood $\mathrm{pCO}_{2}(38,39)$. Therefore, tubular $\mathrm{CO}_{2}$ is lost in transit from the superficial distal tubule to the inner medullary collecting tubule. Bengele et al. (39) and Gougoux et al. (32) explained the findings of an inner medullary collecting duct $\mathrm{pCO}_{2}$ lower than that of the blood by postulating a loss of luminal $\mathrm{CO}_{2}$ by diffusional flux into the lining epithelium. We think that this loss of tubular $\mathrm{CO}_{2}$ (and thereby final urine $\mathrm{CO}_{2}$ ) requires that $\mathrm{H}^{+}$secretion be enhanced and cell $\mathrm{CO}_{2}$ consumed in the process of bicarbonate regeneration. As $\mathrm{H}^{+}$ is secreted into a bicarbonate-poor luminal fluid, ammonium and acid phosphate are preferentially formed, thereby resulting in cell $\mathrm{CO}_{2}$ consumption. This results in the creation of a lumen-to-cell and peritubular blood-to-cell $\mathrm{CO}_{2}$ gradient and tubular $\mathrm{CO}_{2}$ removal.

The titration of secreted hydrogen ions by nonbicarbonate buffer must result in the formation of either ammonium or titratable acidity or both. That urinary $\mathrm{pH}$ fell while titratable acidity and ammonium excretion increased in response to hypercapnia (Table II) is also consistent with the notion that the low $\mathrm{U}-\mathrm{B} \mathrm{pCO}_{2}$ of these rats was achieved in association with enhanced collecting duct $\mathrm{H}^{+}$secretion. The increase in ammonium excretion observed in the second hour of sustained hypercapnia was unassociated with a fall in urine $\mathrm{pH}$ (Table II), which suggests that ammonia production increased. This is in agreement with several studies showing that overall kidney acidification is increased during hypercapnia (48-56) and with recent work showing a prompt adaptive increase in ammoniagenesis in response to acute hypercapnia (57). While proximal nephron segments are the major site of ammonia production, it is now known that a large portion of ammonium and net acid excreted in the final urine are added to the medullary collecting during respiratory acidosis (39) as well as metabolic acidosis $(58,59)$.

Based on all the above considerations, we believe that there is no evidence for the notion that distal acidification is decreased during acute hypercapnia (23). In view of recent direct studies showing that hypercapnia does not increase acidification above normal in either the superficial distal tubule (60) or in the inner medullary collecting duct (39), it seems likely that during hypercapnia acidification is either normal or enhanced only in the outer portion of the medullary collecting duct and/or the cortical collecting duct.

In conclusion, this study shows that hypercapnic rats have a urinary $\mathrm{pCO}_{2}$ lower than systemic blood $\mathrm{pCO}_{2}$ when the urine is acid and when it is alkalinized in the face of accelerated carbonic acid dehydration. These findings suggest that during acute hypercapnia, $\mathrm{CO}_{2}$ is removed from the collecting duct owing to consumption of cell $\mathrm{CO}_{2}$ in the process of bicarbonate regeneration via collecting duct $\mathrm{H}^{+}$secretion and titration of nonbicarbonate buffer. During bicarbonate loading, rats with hypercapnia have a $\mathrm{U}-\mathrm{B} \mathrm{pCO}_{2}$ lower than or equal to that of normocapnic control rats, but the rise in urine $\mathrm{pCO}_{2}$ elicited by this maneuver when blood $\mathrm{pCO}_{2}$ is kept constant is equal or higher in hypercapnic rats than in normocapnic rats, depending on the prevailing blood $\mathrm{pH}$. In hypercapnic rats, the $\mathrm{U}-\mathrm{B} \mathrm{pCO}_{2}$ underestimates collecting duct $\mathrm{H}^{+}$secretion because this parameter is artificially influenced by systemic blood $\mathrm{pCO}_{2}$, a variable that does not reflect vasa recta $\mathrm{pCO}_{2}$ during bicarbonate loading. The $\Delta \mathrm{pCO}_{2}$ is a more appropriate qualitative index of collecting duct $\mathrm{H}^{+}$secretion than the $\mathrm{U}-\mathrm{B}$ $\mathrm{pCO}_{2}$, because it is not influenced by systemic blood $\mathrm{pCO}_{2}$ and takes into account the urine $\mathrm{pCO}_{2}$ prevailing before bicarbonate loading. A more precise evaluation of collecting duct $\mathrm{H}^{+}$secretion requires the infusion of carbonic anhydrase to estimate the amount of $\mathrm{pCO}_{2}$ generated from $\mathrm{H}^{+}$secretion and titration of bicarbonate buffer when carbonic acid dehydration is accelerated and when it is delayed.

\section{Acknowledgments}

This paper received support from a National Institutes of Health grant (AM20170) and a Veterans Administration Merit Review Board grant.

\section{References}

1. Pitts, R. F., and W. D. Lotspeich. 1946. Bicarbonate and the renal regulation of acid-base balance. Am. J. Physiol. 147:138-154.

2. Ryberg, C. 1948. Some investigations on the carbon dioxide tension of the urine in man. Acta Physiol. Scand. 15:123-139.

3. Kennedy, T. J., Jr., J. Orloff, and R. W. Berliner. 1952. Significance of carbon dioxide tension in the urine. Am. J. Physiol. 169:596-608.

4. Ochwadt, B. K., and R. F. Pitts. 1956. Effects of intravenous infusion of carbonic anhydrase on carbon dioxide tension of alkaline urine. Am. J. Physiol. 185:426-429.

5. Dorman, P. J., W. J. Sullivan, and R. F. Pitts. 1954. Factors determining carbon dioxide tension in urine. Am. J. Physiol. 179:181187.

6. Rector, F. C., Jr., R. M. Portwood, and D. W. Seldin. 1959. Examination of the mixing hypothesis as an explanation for elevated urinary $\mathrm{CO}_{2}$ tensions. Am. J. Physiol. 197:861-864.

7. Kennedy, T. J., M. Eden, and R. W. Berliner. 1957. Interpretation of urine $\mathrm{CO}_{2}$ tension. Fed. Proc. 16:72.

8. Portwood, R. M., D. W. Seldin, F. C. Rector, Jr., and R. Cade. 1959. The relation of urinary $\mathrm{CO}_{2}$ tension to bicarbonate excretion. $J$. Clin. Invest. 38:770-776.

9. DuBose, T. D., Jr. 1982. Hydrogen ion secretion by the collecting duct as a determinant of the urine to blood $\mathrm{pCO}_{2}$ gradient in alkaline urine. J. Clin. Invest. 69:145-156.

10. Graber, M. C., C. R. Caflish, H. H. Bengele, and E. A. Alexander. 1982. Elevated urinary $\mathrm{pCO}_{2}$ in the rat: an intrarenal event. Kidney Int. 21:795-799.

11. Pak Poy, R. K., and O. Wrong. 1960. The urinary $\mathrm{pCO}_{2}$ in renal disease. Clin. Sci. 19:631-639.

12. Reid, E. L., and A. G. Hills. 1965. Diffusion of carbon dioxide out of the distal nephron in man during antidiuresis. Clin. Sci. (Oxford). 28:15-28.

13. Steinmetz, P. R., Q. Al-Awquati, and W. J. Lawson. 1976. Renal tubular acidosis. Am. J. Med. Sci. 271:41-51.

14. Arruda, J. A. L., L. Nascimento, P. K. Mehta, D. R. Rademacher, J. T. Sehy, C. Westenfelder, and N. A. Kurtzman. 1977. The critical importance of urinary concentrating ability in the generation of urinary carbon dioxide tension. J. Clin. Invest. 60:922-935.

15. Maren, T. 1978. Carbon dioxide equilibria in the kidney: the problems of elevated carbon dioxide tension, delayed dehydration, and disequilibrium pH. Kidney Int. 14:395-405.

16. Kurtzman, N. A., and J. A. L. Arruda. 1978. Physiologic significance of urinary carbon dioxide tension. Mineral. Electrolyte Metab. 1:241-246.

17. Arruda, J. A. L., M. K. Roseman, J. T. Sehy, P. K. Mehta, and N. A. Kurtzman. 1980. In vivo and in vitro studies of urinary acidification. Miner. Electrolyte Metab. 3:122-135. 
18. Halperin, M. L., M. B. Goldstein, A. Haig, M. D. Johnson, and B. J. Stinebaugh. 1974. Studies on the pathogenesis of type I (distal) renal tubular acidosis as revealed by the urinary $\mathrm{pCO}_{2}$ tensions. J. Clin. Invest. 3:669-677.

19. Giammarco, R. A., M. B. Goldstein, M. L. Halperin, and B. J. Stinebaugh. 1976. The effect of hyperventilation on distal nephron hydrogen ion secretion. J. Clin. Invest. 58:77-82.

20. Stinebaugh, B. J., R. Esquenazi, F. X. Schloeder, W. N. Suki M. B. Goldstein, and M. L. Halperin. 1980. Control of the urineblood $\mathrm{pCO}_{2}$ gradient in alkaline urine. Kidney Int. 17:31-39.

21. Gougoux, A., P. Vinay, G. Lemieux, R. Richardson, S. C. Tam, M. B. Goldstein, B. Stinebaugh, and M. C. Halperin. 1980. Effect of blood $\mathrm{pH}$ on distal nephron hydrogen ion secretion. Kidney Int. 17:615-621.

22. Tam, S. C., M. B. Goldstein, B. J. Stinebaugh, C. B. Chen, A. Gougoux, and M. L. Halperin. 1981. Studies on the regulation of hydrogen ion secretion in the collecting duct in vivo: evaluation of factors that influence the urine minus blood $\mathrm{pCO}_{2}$ difference. Kidney Int. 20:636-642.

23. Adrogue, H. J., B. J. Stinebaugh, A. Gougoux, G. Lemieux, P. Vinay, S. C. Tam, M. B. Goldstein, and H. L. Halperin. 1983. Decreased distal acidification in acute hypercapnia in the dog. Am. J. Physiol. 244:F19-F27.

24. Sehy, J. T., M. K. Roseman, J. A. L. Arruda, and N. A. Kurtzman. 1978. Characterization of distal hydrogen ion secretion in acute respiratory alkalosis. Am. J. Physiol. 235:F203-F208.

25. Hulter, H. N., L. P. Ilnicki, J. H. Licht, and A. Sebastian. 1982. On the mechanism of diminished urinary carbon dioxide tension caused by amiloride. Kidney Int. 21:8-13.

26. Cruz-Soto, M., D. C. Batlle, S. Sabatini, J. A. L. Arruda, and N. A. Kurtzman. 1982. Urinary acidification in the rabbit: role of diet and blood pH. Am. J. Physiol. 243:F364-F371.

27. Batlle, D. C., M. Gaviria, J. A. L. Arruda, J. Wynn, and N. A. Kurtzman. 1982. Distal nephron function in patients receiving chronic lithium therapy. Kidney Int. 21:477-485.

28. Batlle, D. C., M. Grupp, M. Gaviria, and N. A. Kurtzman. 1982. Distal renal tubular acidosis with intact capacity to lower urinary pH. Am. J. Med. 72:751-758.

29. Batlle, D. C., K. Itsarayoungyuen, R. Foley, M. Downer, J. A. L. Arruda, and N. A. Kurtzman. 1983. Suppression of distal urinary acidification after recovery from chronic hypocapnia. Am. J. Physiol. 245:F433-F442.

30. Batlle, D. C. 1982. Delta $\mathrm{pCO}_{2}$ rather than urine-blood (U-B) $\mathrm{pCO}_{2}$ as an index of distal acidification. Seminars Nephrol. 2:189-190.

31. Brodsky, W. A., J. F. Miley, J. T. Kaim, and N. P. Shah. 1958. Characteristics of acidic urine after loading with weak organic acids in dogs. Am. J. Physiol. 193:108-122.

32. Gougoux, A., P. Vinay, G. Lemieux, M. Goldstein, B. Stinebaugh, and M. Halperin. 1983. Importance of medullary events in ammonium excretion: studies in acute respiratory acidosis and acute metabolic acidosis. Can. J. Physiol. Pharmacol. 61:35-42.

33. Batlle, D. C., R. Foley, K. Itsarayoungyuen, and N. A. Kurtzman. 1982. Distal acidification (DA) during chronic hypercapnia (CH). Clin. Res. 30:752A. (Abstr.)

34. Uhlich, E., C. A. Baldamus, and K. J. Ullrich. 1968. Verhalten von $\mathrm{CO}_{2}$-Druck und bicarbonat im Gegenstromsystem des Nierenmarks. Pfluegers Arch. Eur. J. Physiol. 303:31-48.

35. Pucacco, L. R., and N. W. Carter. 1978. An improved $\mathrm{pCO}_{2}$ microelectrode. Anal. Biochem. 90:427-434.

36. DuBose, T. D., Jr. 1983. Application of the disequilibrium pH method to investigate the mechanism of urinary acidification. Am. J. Physiol. 245:F535-F544.

37. Gennari, F. J., C. R. Caflisch, C. Johns, D. A. Maddox, and J. T. Cohen. 1982. pCO 2 measurements in surface proximal tubules and peritubular capillaries of the rat kidney. Am. J. Physiol. 242:F78F85.

38. Graber, M. L., H. H. Bengele, J. H. Schwartz, and E. A Alexander. 1981. $\mathrm{pH}$ and $\mathrm{pCO}_{2}$ profiles of the rat inner medullary collecting duct. Am. J. Physiol. 241(Renal Fluid Electrolyte Physiol. 10):F659-F668.

39. Bengele, H. H., M. L. Graber, and E. A. Alexander. 1983. Effect of respiratory acidosis on acidification by the medullary collecting duct. Am. J. Physiol. 244:F89-F94.

40. Arruda, J. A. L., L. Nascimento, S. K. Kumar, and N. A. Kurtzman. 1977. Factors influencing the formation of urinary carbon dioxide tension. Kidney Int. 11:307-317.

41. Kurtzman, N. A. 1970. Relationship of extracellular volume and $\mathrm{CO}_{2}$ tension to renal bicarbonate reabsorption. Am. J. Physiol. 219:1299-1304.

42. Cunnarro, J. A., and M. W. Weiner. 1974. A comparison of methods for measuring urinary ammonium. Kidney Int. 5:303-305.

43. Maren, T. H. Simplified micromethod for the determination of carbonic anhydrase and its inhibitors. J. Pharmacol. Exp. Ther. 130:26-29.

44. Batlle, D. C., M. Downer, and N. A. Kurtzman. 1983. Failure of the urine-blood $\mathrm{pCO}_{2}$ gradient to portray distal acidification during hypocapnia. Clin. Res. 31:748. (Abstr.)

45. Cohen, L. H., and P. R. Steinmetz. 1980. Control of active proton transport in turtle urinary bladder by cell pH. J. Gen. Physiol. 76:381-393.

46. Steinmetz, P. R., and O. S. Anderson. 1982. Electrogenic proton transport in epithelial membranes. J. Membr. Biol. 65:155174.

47. Rector, F. C., Jr. 1973. Acidification of the urine. In Handbook of Physiology. Renal Physiology. J. Orloff and R. W. Berliner, editors. American Physiological Society. Washington, DC. 431-454.

48. Brazeau, P., and A. Gilman. 1953. Effect of plasma $\mathrm{pCO}_{2}$ tension on renal tubular reabsorption of bicarbonate. Am. J. Physiol. 175:33-38.

49. Barker, E. S., R. B. Singer, J. R. Elkinson, and J. K. Clark. 1957. The renal response in man to acute experimental respiratory alkalosis and acidosis. J. Clin. Invest. 36:515-529.

50. Giebisch, G., L. Berger, and R. F. Pitts. 1955. The extrarenal response to acute acid-base disturbances of respiratory origin. J. Clin. Invest. 34:231-245.

51. Relman, A. S., B. Etsten, and W. B. Schwartz. 1953. The regulation of renal bicarbonate reabsorption by plasma carbon dioxide tension. J. Clin. Invest. 32:972-978.

52. Dorman, P. J., W. J. Sullivan, and R. F. Pitts. 1954. The renal response to acute respiratory acidosis. J. Clin. Invest. 33:82-90.

53. Levine, D. Z. 1971. Effect of acute hypercapnia on proximal tubular water and bicarbonate reabsorption. Am. J. Physiol. 221:11641170.

54. Rector, F. C., Jr., D. W. Seldin, A. D. Roberts, Jr., and J. S. Smith. 1960. The role of plasma $\mathrm{CO}_{2}$ tension and carbonic anhydrase activity in the renal reabsorption of bicarbonate. J. Clin. Invest. 39: 1706-1721.

55. Cogan, M. G. 1984. Effects of acute alterations in $\mathbf{p C O}_{2}$ on proximal $\mathrm{HCO}_{3}^{-}, \mathrm{Cl}^{-}$, and $\mathrm{H}_{2} \mathrm{O}$ reabsorption. Am. J. Physiol. 246: F21-F26.

56. Hamid, B., and R. L. Tannen. 1984. Adaptive changes in renal acidification in response to respiratory acidosis. Clin. Res. 533A. (Abstr.)

57. Gougoux, A., P. Vinay, M. Cardoso, M. Duplain, and G. Lemieux. 1982. Immediate adaptation of the dog kidney to acute hypercapnia. Am. J. Physiol. 243:F227-F234.

58. Sajo, I. M., M. B. Goldstein, H. Sonnenberg, B. J. Stinebaugh, D. R. Wilson, and M. L. Halperin. 1981. Sites of ammonia addition to tubular fluid in rats with chronic metabolic acidosis. Kidney Int. 20:353-358.

59. Buerkert, J., D. Martin, and D. Trigg. 1983. Segmental analysis of the renal tubule in buffer production and net acid formation. Am J. Physiol. F442-F454.

60. Lucci, M. S., L. R. Pucacco, N. W. Carter, and T. D. DuBose. 1982. Evaluation of bicarbonate transport in rat distal tubule: effects of acid-base status. Am. J. Physiol. 243(Renal Fluid Electrolyte Physiol. 12):F335-F341. 